\title{
Groundwater recharge estimation using HYDRUS 1D model in Alaşehir sub-basin of Gediz Basin in Turkey
}

\author{
Serhat Tonkul • Alper Baba • Celalettin Şimșek • \\ Seda Durukan • Ali Can Demirkesen • Gökmen Tayfur
}

Received: 18 February 2019 / Accepted: 27 August 2019/Published online: 5 September 2019

(C) Springer Nature Switzerland AG 2019

\begin{abstract}
Gediz Basin, located in the western part of Turkey constituting $2 \%$ land of the country, has an important groundwater potential in the area. Alasehir sub-basin, located in the southeast of the Gediz Basin and subject to the extensive withdrawal for the irrigation, constitutes the study area. Natural recharge to the sub-basin due to precipitation is numerically investigated in this study. For this purpose, 25 research wells, whose depths range from 20 to $50 \mathrm{~m}$, were drilled to observe the recharge and collect the necessary field data for the numerical model. Meteorological data were collected from 3 weather stations installed in the study area. The numerical model HYDRUS was calibrated using the field water content data. Soil characterization was done on the core samples; the aquifer characterization was performed, and the alluvial aquifer recharge due to precipitation was calculated. As a result, the computed recharge value ranges from 21.78 to $68.52 \mathrm{~mm}$, with an
\end{abstract}

S. Tonkul $\cdot$ A. Baba $(\bowtie) \cdot$ G. Tayfur

Department of Civil Engineering, İzmir Institute of Technology, İzmir, Turkey

e-mail: alperbaba@iyte.edu.tr

C. Şimșek

Torbalı Vocational High School, Dokuz Eylül University, İzmir, Turkey

\section{S. Durukan}

Manisa Vocational School of Technical Sciences, Manisa Celal Bayar University, Manisa, Turkey

A. C. Demirkesen

Department of City and Regional Planning, İzmir Institute of Technology, İzmir, Turkey average value of $43.09 \mathrm{~mm}$. According to the numerical model, this amount of recharge corresponds to $10 \%$ of the amount of annual rainfall.

Keywords Aquifer recharge · Alașehirsub-basin - Gediz Basin · Precipitation · Model calibration and validation . Numerical modeling

\section{Introduction}

Traditional water storage areas are known to be dams. However, dams have various disadvantages such as evaporation losses (about $2 \mathrm{~m}$ per year in dry and warm climates), potential and structural losses, sediment deposition, and ecological and environmental factors (Devine 1995; Knoppers and van Hulst 1995; Pearce 1992). Dams may not be suitable for long-term water storage. On the other hand, groundwater recharge and underground storage areas have the advantage of virtually zero evaporation from the aquifer. For this reason, groundwater recharge has become a growing practice in many parts of the world.

Estimation of groundwater recharge is crucial for sustainability of aquifers, management of water resources, and water potential in a basin (De Silva 2015). Recharge estimation is a difficult process to be determined in areas where the groundwater table is deep and limited by the availability of water on the soil surface due to external conditions such as amount of nutrients, evaporation, precipitation, temperature, and climatic factors (De Silva 2015). It is becoming a more 
important issue in the future as the rapidly growing population needs more water and requires more storage of water to save in case of water shortage.

Natural recharge of the groundwater is the amount of water reaching the water table by draining down through the vadose zone (Rushton and Ward 1979). Groundwater recharge affects the amount of water that can be kept in an aquifer in the long term and it is therefore of great importance in the assessment of any groundwater resources. The amount of water from an aquifer depends primarily on the recovery of groundwater.

Being an agricultural and industrial region, the agriculture and animal husbandry is the subsistence of the population in Alaşehir sub-basin. The recent reduction in precipitation and high evaporation rates in the region has increased the groundwater requisition for agricultural irrigation. Within the context of this study, the groundwater recharge estimation is carried out for the sustainability of alluvium aquifer in the Alaşehir subbasin.

\section{Description of the study area}

Gediz Basin is one of the most important basins covering about $2 \%$ of Turkey. Alaşehir sub-basin, which is the study area, is located in the south-eastern part of Gediz basin and constitutes $15.8 \%$ of the basin (Fig. 1). Alaşehir sub-basin is $140 \mathrm{~km}$ long and $15 \mathrm{~km}$ wide between Alaşehir and Salihli in the northwestsoutheast direction. The total drainage area of Alașehir sub-basin is $2710.5 \mathrm{~km}^{2}$ and the sub-basin has a very wide area. The altitude of the sub-basin, which is a typical depression basin, ranges from 83 to $2155 \mathrm{~m}$ from the sea level. The upper parts of the basin are surrounded by Bozdağ and Seyran mountains. In the study area, agricultural irrigation is made extensively. The water used for agricultural irrigation is provided from the groundwater in the basin, Avşar Dam in the west of the basin and Derbent Dam in the south.

\section{Geology}

The Paleozoic-aged Menderes metamorphic rocks form the basement of the Alașehir plain and are observed outcropping in the eastern and western parts of the plain. The Menderes metamorphic rocks consist of mica and chlorite schists in their lower levels and dolomitic marble in their upper sections (Fig. 2). These schists are nearly impermeable and therefore do not supply significant amounts of groundwater. The Neogene Formation, formed of limestone and claystone, overlies basement rock. This formation is widely observed in the western part of the study area. Finally, Quaternary alluvial layers overlie the basement and the Neogene Formation in the study area. The thickness of the alluvial layer ranges from 50 to $250 \mathrm{~m}$ in Alaşehir plain (Fig. 3).

The evaluation of the geological characterization results revealed that the most important water-bearing units in the study area are alluvial aquifer. The Quaternary surficial aquifer is composed of alluvial deposits. It is the main water-supplying strata within the study area. Based on the analysis of the water table, the groundwater flow direction in the project area was determined to be from south to northwest in alluvial aquifer.

Hydrogeological characteristics of geological units

Determination of hydraulic parameters of saturated zone in aquifer in the study area is important for hydrogeological studies. In this context, pumping tests were performed in wells drilled for determination of hydraulic parameters of saturated zone of Alluvium and Neogene aquifer. For the hydraulic parameters of the aquifer, 10 pumping wells were opened (Fig. 4). For the pumping wells, a submersible pump capable of production with a flow rate of $3-5 \mathrm{~L} / \mathrm{s}$ is used. Production was made from wells and decreases were observed. According to the pumping test data, hydraulic parameter data set was formed. Since the Neogene units did not offer a scattered and monolithic area in the area, and due to the lack of sufficient data, a distribution map was not established. The alluvium aquifer was subjected to aquifer-based analysis because it was the most important aquifer in the area. Specific flow rate, transmissivity, storage coefficient, and hydraulic conductivity, which are obtained from pumping tests, are discussed in detail.

\section{Specific flow rate $\left(Q_{s}\right)$}

The specific flow rate of the aquifer is defined as the flow corresponding to $1-\mathrm{m}$ drop. The unit is $\mathrm{L} / \mathrm{s} / \mathrm{m}$. Specific flow rate was obtained from the pump wells drilled in the study area. The specific flow rate for the alluvium aquifer ranged from 0 to $23 \mathrm{~L} / \mathrm{s} / \mathrm{m}$, with an 


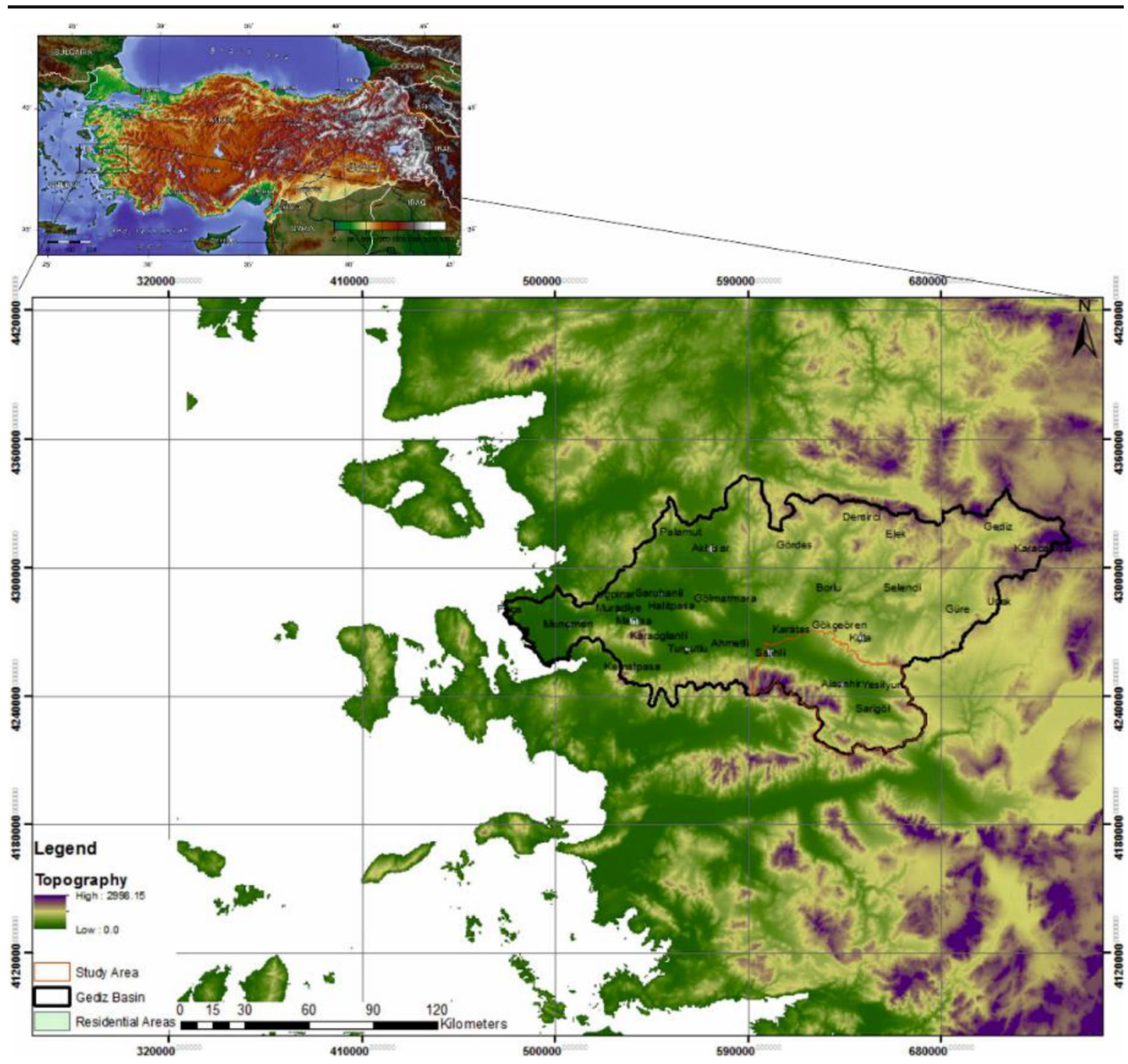

Fig. 1 Location map of the study area

average of $9 \mathrm{~L} / \mathrm{s} / \mathrm{m}$. Alluvium offers a very wide range of specific flow rates according to the material properties of the aquifer (Fig. 5). Particularly, the alluvial fans have a high specific flow rate, while the middle and eastern sections with fine-grained material offer a lower specific flow rate. These areas are Tepeköy, Baklacı, and Sarıgöl which are dominated by clays. The specific flow rates of the Neogene clastic units range from 0.06 to $18.26 \mathrm{~L} / \mathrm{s} / \mathrm{m}$ and the average is $3.44 \mathrm{~L} / \mathrm{s} / \mathrm{m}$. According to the average specific flow rate, alluvial aquifer flow values were higher than Neogene units. In this context, the alluvium aquifer is an important unit in terms of quenching potential (Fig. 5).

\section{Transmissivity (T)}

The transmissivity value known as the water conduction capacity along the thickness of the aquifer was obtained from the pump wells opened in the project site and from the previously opened well data. It is one of the parameters that are important in the evaluation of the potential of the groundwater to be provided by the aquifer. Transmissivity values were obtained with the help of pumping test data. In addition, a data set was formed with alluvium aquifer transmissivity values determined by DSI. With all these data, the transmissivity value for the alluvium aquifer ranged from 8 to $5694 \mathrm{~m}^{2} /$ day and the 


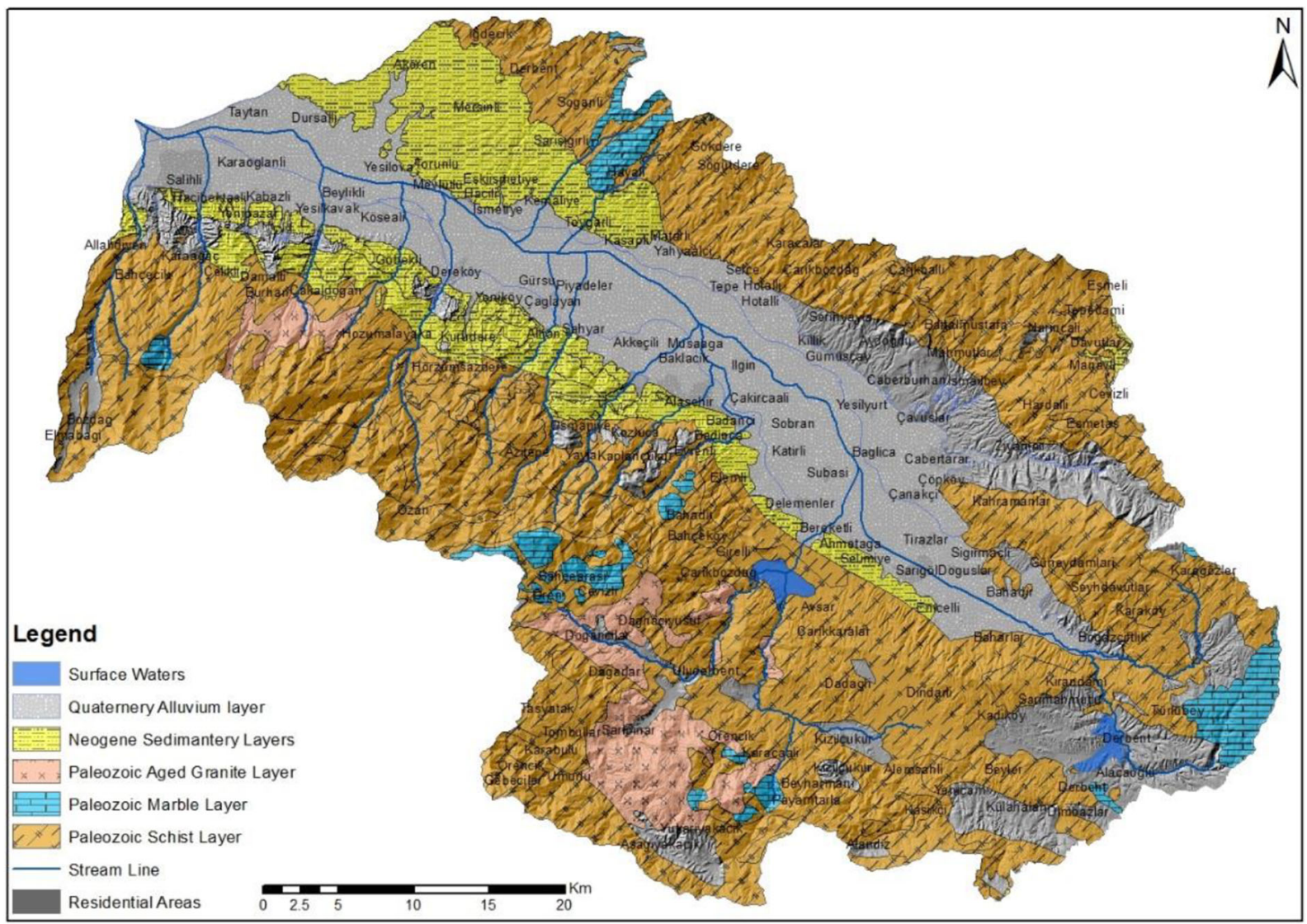

Fig. 2 Geology map of the study area

average value was determined as $782 \mathrm{~m}^{2} /$ day. Transmissivity distribution map is given in Fig. 6 .

As can be seen in Fig. 6, areas with high conductivity in terms of groundwater potential show similar changes with the specific flow rate map. High value was obtained in a well opened in sandstone. Especially in Tepeköy and the surrounding area, due to the high percentage of clay material, the permeability is low, and therefore, the transmissivity value is parallel (Fig. 6).

\section{Storage coefficient}

The storage coefficient is an important parameter for determining the volume of water in the aquifer, which is difficult to determine in the field. In order to determine the storage coefficient, the research well should be opened near the pumping well and the drop should be monitored from this well. In the study area, a storage coefficient distribution map was created for the alluvium aquifer using pumping test data and the storage coefficient data previously made by DSİ (Fig. 7).
The aquifer storage coefficient in the study area ranged from 0.01 to 0.35 and an average of 0.07 was obtained. In some areas, less than 0.01 is obtained and it is understood that the aquifer offers a semi-confined feature. In Neogene units, however, storage coefficient was obtained in two wells and ranged from 0.018 to 0.067 .

\section{Hydraulic conductivity}

Hydraulic conductivity is a measure of the water transmission capacity of soils. Hydraulic conductivity is a parameter that can be determined in the laboratory and in the field. Permeability tests in the laboratory are carried out with constant level permeability tests on coarse grained soils, while falling level permeability tests are applied on fine-grained units such as sand and clay. In the field, hydraulic conductivity can be calculated from pumping test (withdrawal water from soil) and borehole tests (sending water to soil). In this study, hydraulic conductivity values were obtained by 


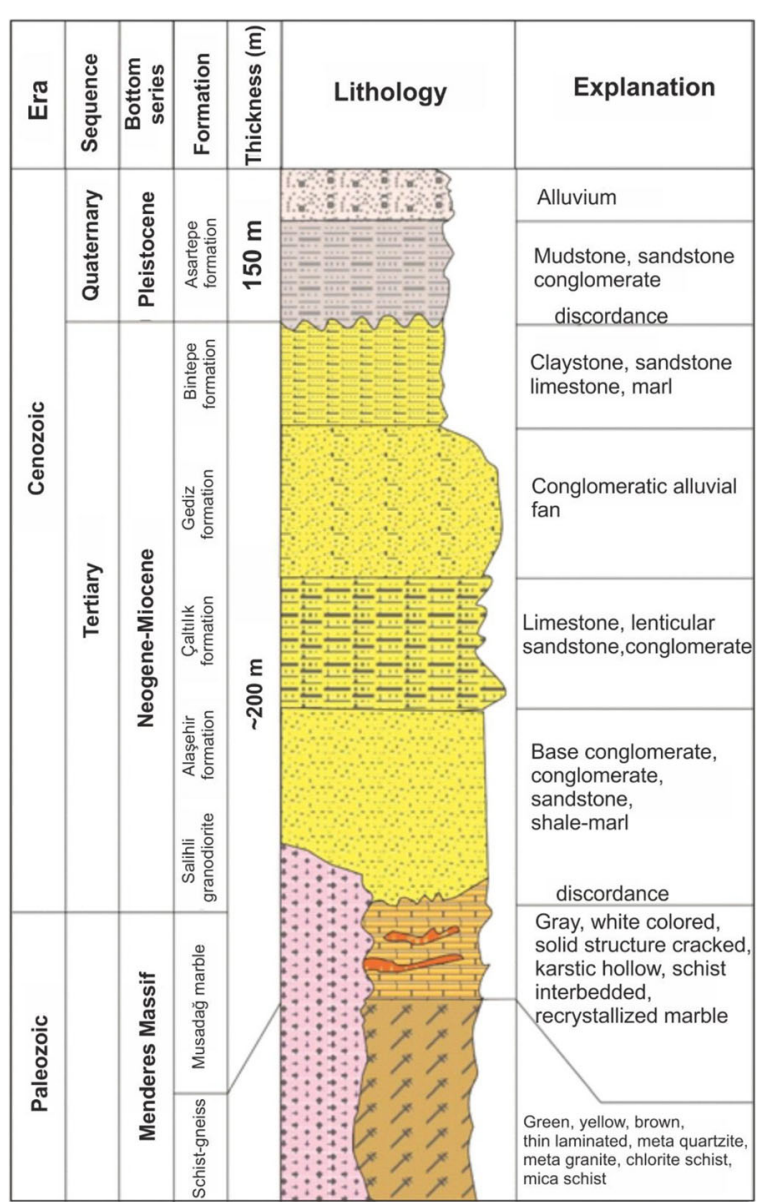

Fig. 3 Generalized stratigraphic section of the study area (modified from Çiftçi and Bozkurt 2009)

borehole tests in the field. In addition to the values obtained from the pump tests, well test data belonging to DSI have been used. Finally, hydraulic conductivity was obtained for the alluvium aquifer (Fig. 8).

It was seen that the calculated hydraulic conductivity values are low and close to each other. This is due to the fact that the soil groups are dominated by fine-grained soils at different depths and the alluvium in the region is highly heterogeneous. The permeability values are ranging from 0.01 to $46 \mathrm{~m} /$ day in the study area (Fig. 8).

\section{Material and methods}

Research wells

The groundwater estimation study in Alasehir Plain was conducted as a two-stage process: (1) field studies and
(2) HYDRUS 1D modeling. During the first stage, a drilling application survey was conducted. In order to define the alluvium aquifer lithology of the study area, research wells with a total depth of $1080 \mathrm{~m}$ were drilled at 25 points (SK-1 to SK-25) (Fig. 9). These wells represent the observation wells in the study area. These drilled wells were used to determine the hydraulic properties of the vadose zone of aquifer. The depth of the research wells ranged from 20 to $50 \mathrm{~m}$. The well locations were chosen such that they are located far from the pollutant effects and they correctly reflect the properties of the alluvium aquifer in the study area.

In order to determine the vadose zone hydraulic conductivity value, falling permeability test was applied during the well operation. In this study, hydraulic conductivity values which were obtained by borehole tests in the field were used in HYDRUS 1D model program. In addition, 3 weather stations were installed at (MT-1), (MT-2), and (MT-3) for measuring hourly meteorological data such as precipitation and air temperature. From July 16,2016 , to July 31 , 2017, the meteorological data were collected from these weather stations on a regular basis. Thornthwaite method (Thornthwaite 1948) was used to obtain the runoff, actual and potential evapotranspiration in the study area.

\section{HYDRUS 1D model}

In the second stage, HYDRUS 1D model was applied to predict recharge rate for the alluvial aquifer. HYDRUS $1 \mathrm{D}$ is a computer-based program for numerically solving Eq. (1), developed by Richards (1931), for transient flow in saturated and unsaturated soils (Blonquist et al. 2006).

$\frac{\partial \theta(h)}{\partial t}=\frac{\partial}{\partial z}\left(K(h) \frac{\partial h}{\partial z}\right)+\frac{\partial K(h)}{\partial z}-S(h)$

where $K$ is the hydraulic conductivity $\left[\mathrm{L} \mathrm{T}^{-1}\right], \theta$ is the water content $[-], h$ is the pressure head $[\mathrm{L}], z$ is the vertical distance [L], $t$ is the time [T], and $S$ is the sink term $\left[\mathrm{L}^{3} \mathrm{~L}^{-3} \mathrm{~T}^{-1}\right]$. The first term stands for the effect of capillarity on water movement, while the second term explains the effect of gravity on water movement. As can be seen from the Eq. (1), there are two dependent variables: water content and pressure head. The Richards equation can be solved numerically using appropriate initial and boundary conditions. 


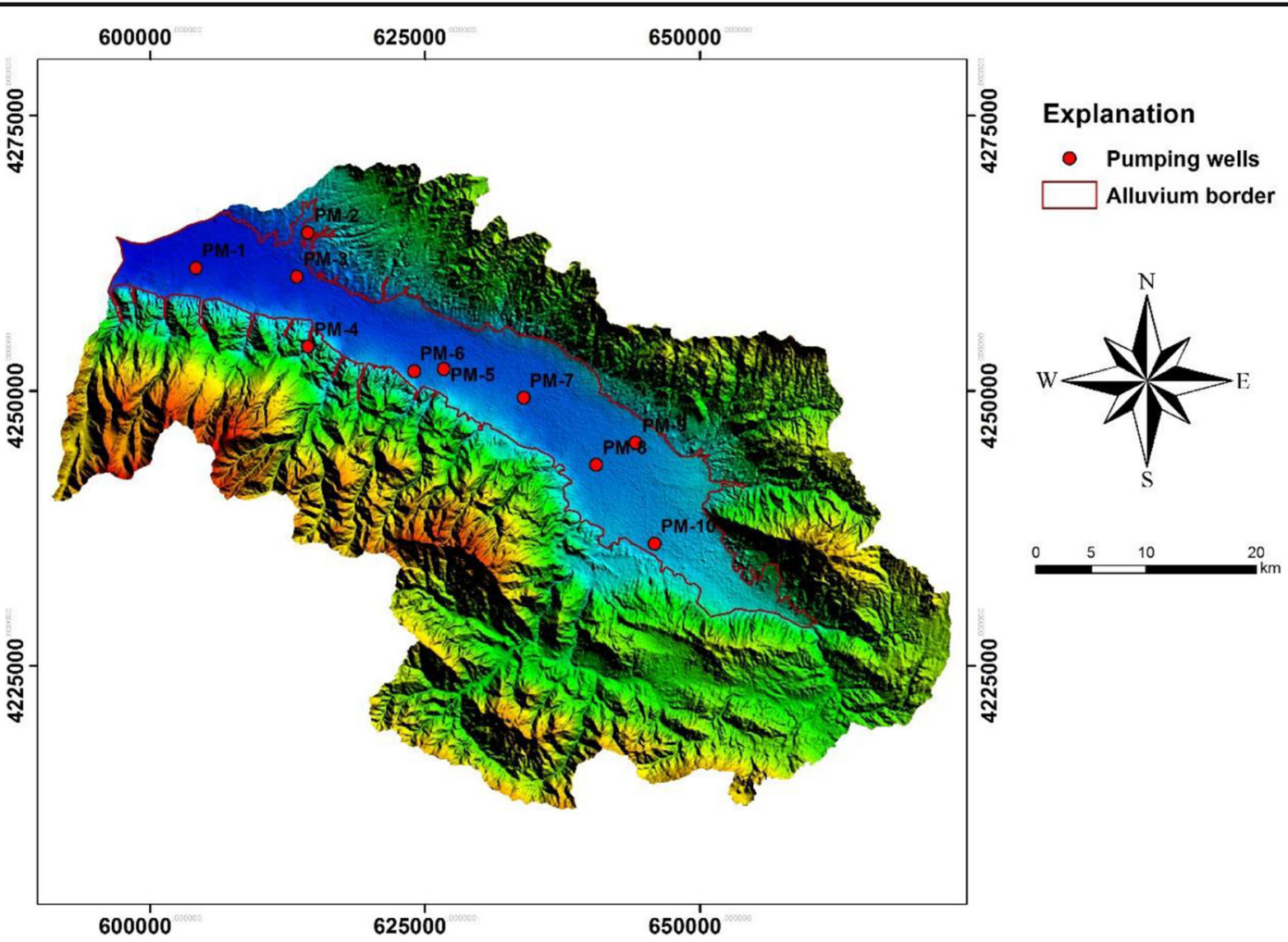

Fig. 4 Pumping wells in the study area

HYDRUS 1D allows the use of 5 different analytical models for hydraulic features. These are Van Genuchten (1980), Brooks and Corey (1964), Vogel and Cislerova
(1988), Kosugi (1996), and Durner (1994). The hydraulic features of Van Genuchten (1980) were chosen in this study because hydraulic properties are generally

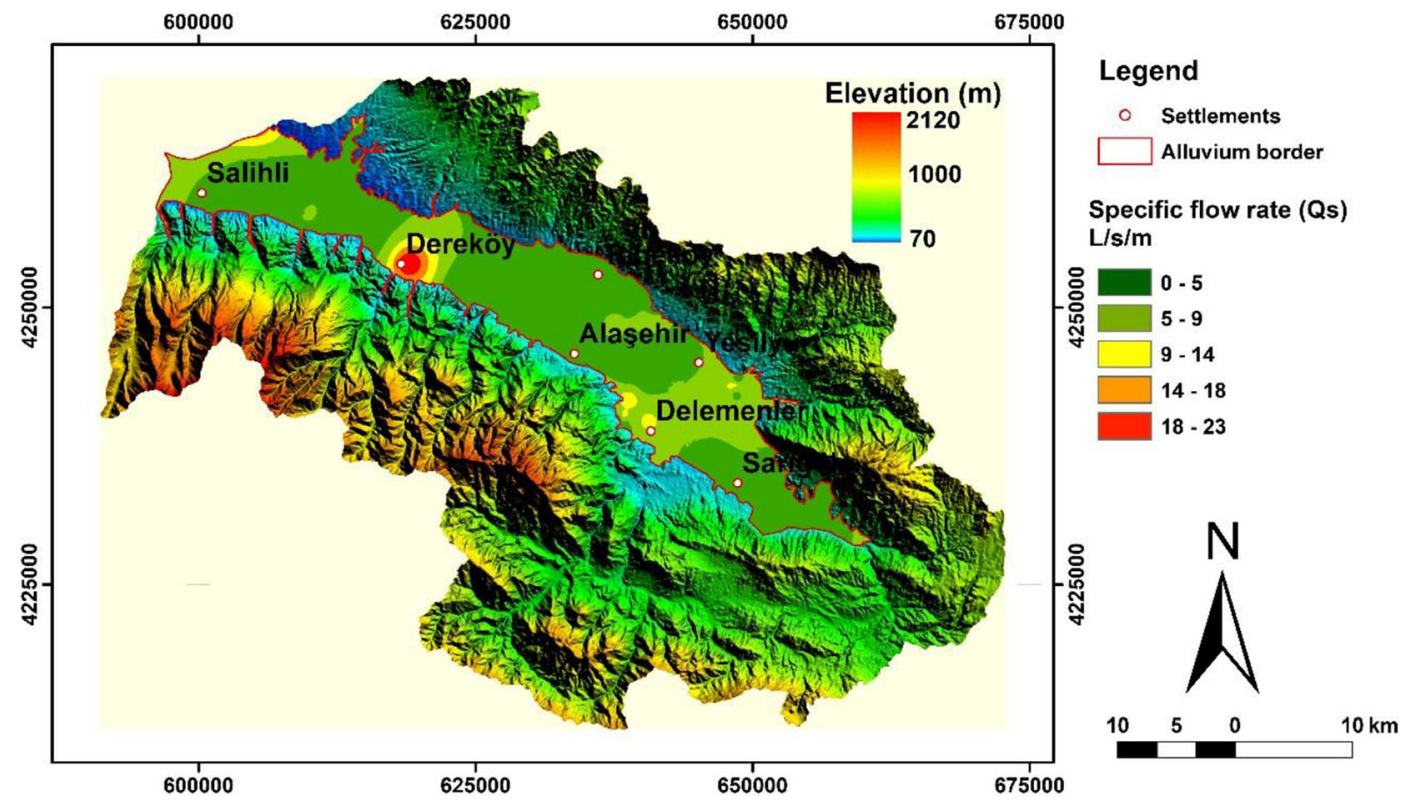

Fig. 5 Specific flow rate $\left(Q_{\mathrm{s}}\right)$ of the geological units in the area 


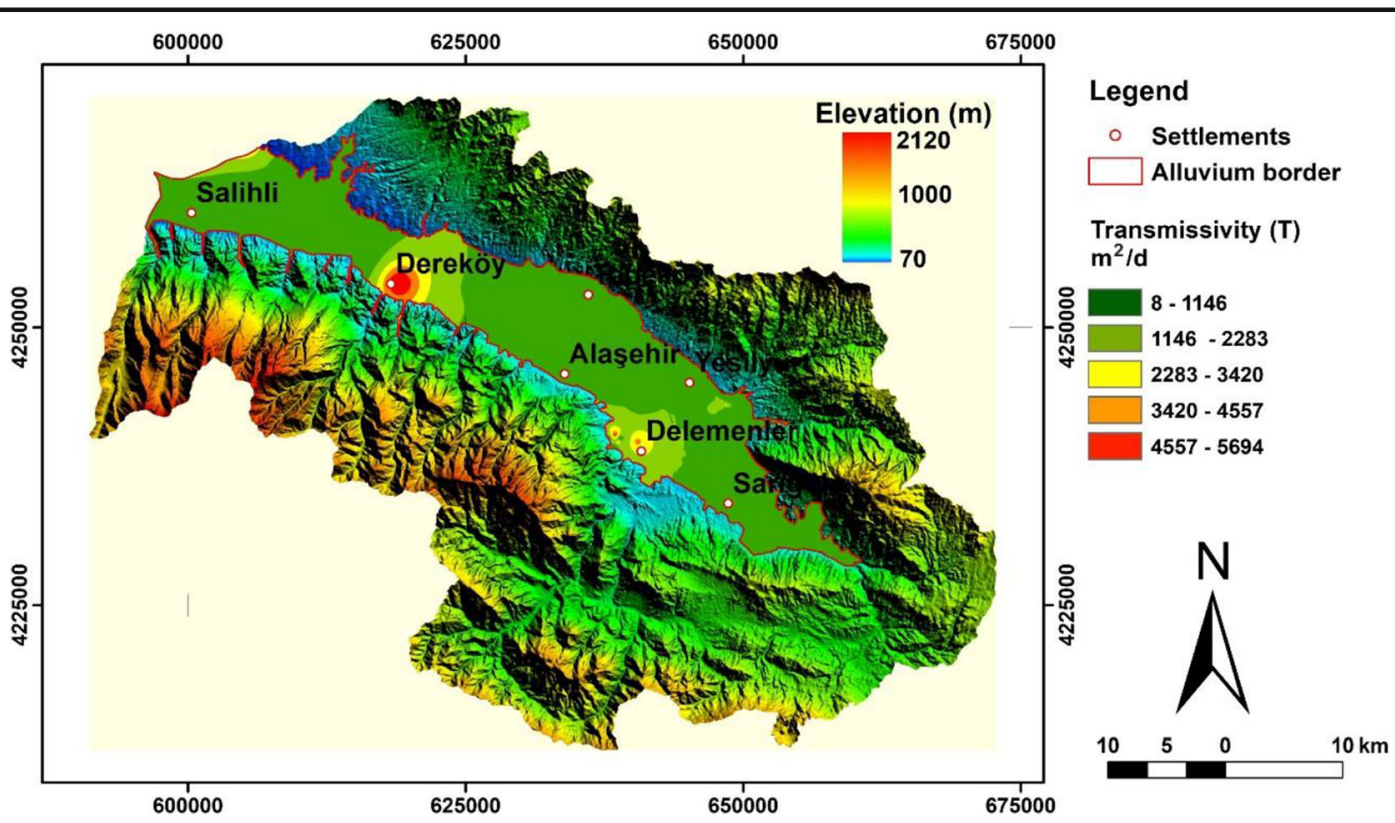

Fig. 6 Transmissivity $(T)$ values of the geological units

described using the pore size distribution model of Mualem (1976) together with the water retention function defined by Van Genuchten (1980).

The most widely used water retention function was developed by Van Genuchten (1980); where $S_{\mathrm{e}}(\mathrm{h})$ is the soil water saturation; $\alpha\left[\mathrm{L}^{-1}\right], n[-]$, and $\mathrm{m}[-]$ are the auxiliary parameters. Here, it is written as $S_{\mathrm{e}}$ (h) instead of $S_{\mathrm{e}}$ to emphasize that the effective saturation is a function of the pressure head.

$$
S_{\mathrm{e}}(h)=\frac{1}{\left[1+(-\alpha h)^{n}\right]^{m}} \quad \text { (2) } \quad \theta(h)=\frac{\theta_{s}-\theta_{r}}{\left[1+(-\alpha h)^{n}\right]^{m}}+\theta_{r}
$$

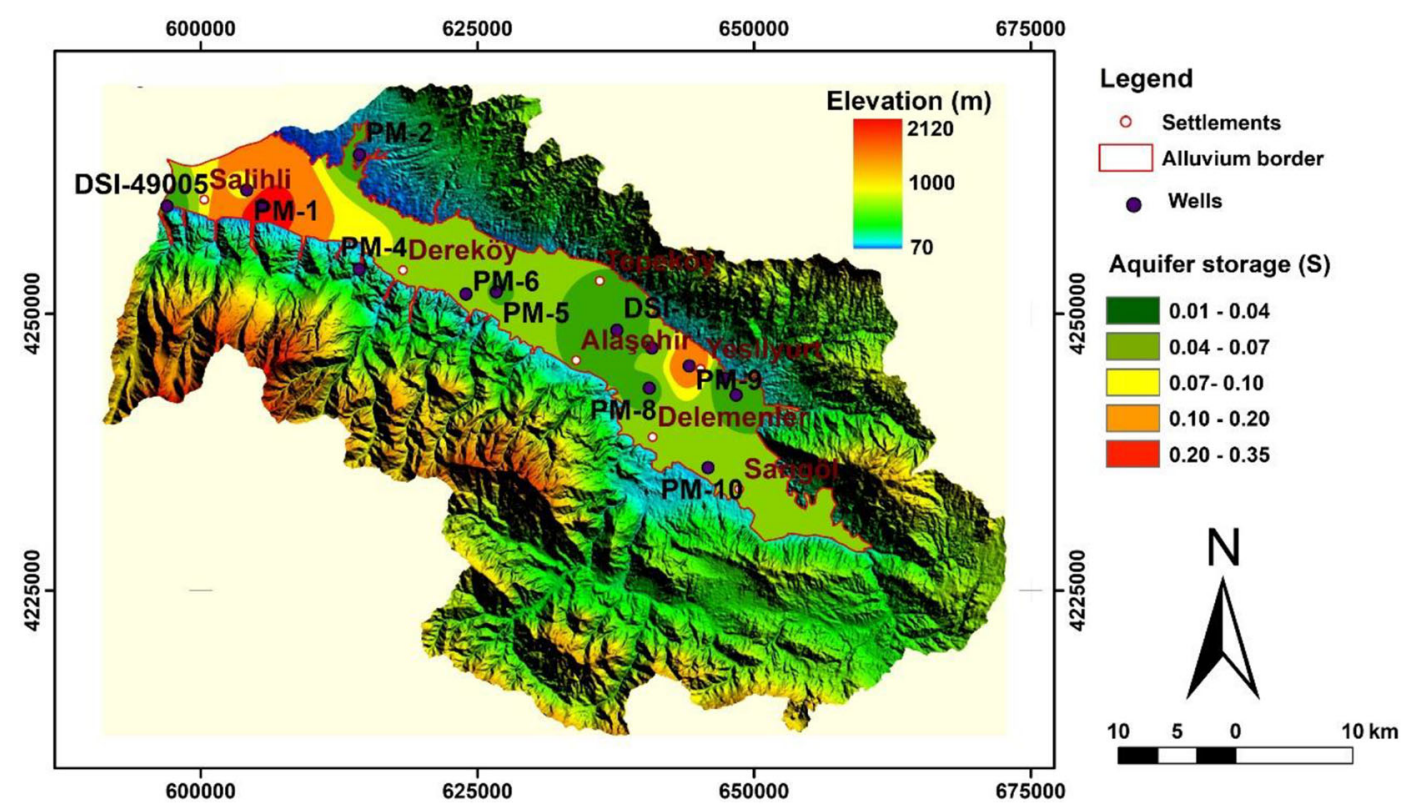

Fig. 7 Storage coefficient of the geological units 


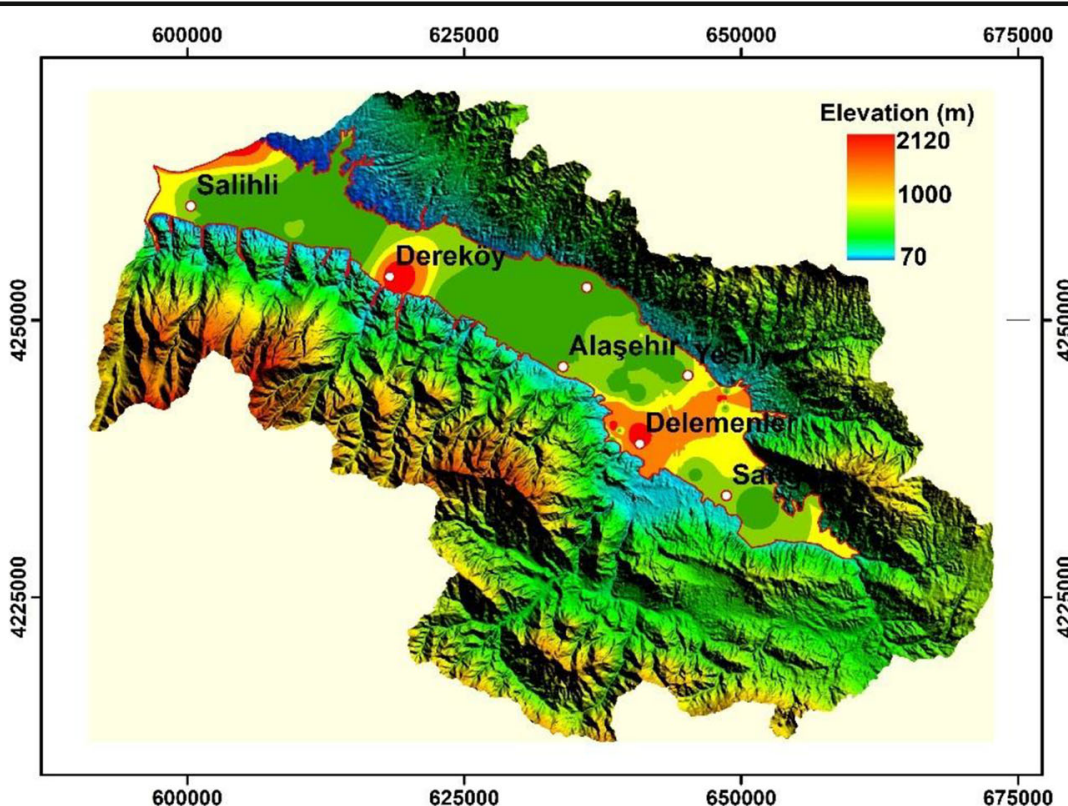

Legend

- Settlements

Alluvium border

Hydraulic conductivity (K) $\mathrm{m} / \mathrm{d}$

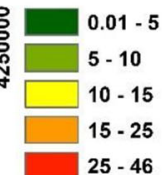

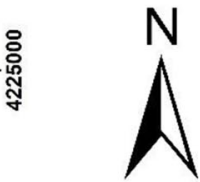

10

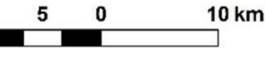

Fig. 8 Hydraulic conductivity values of alluvium aquifer in vadose zone

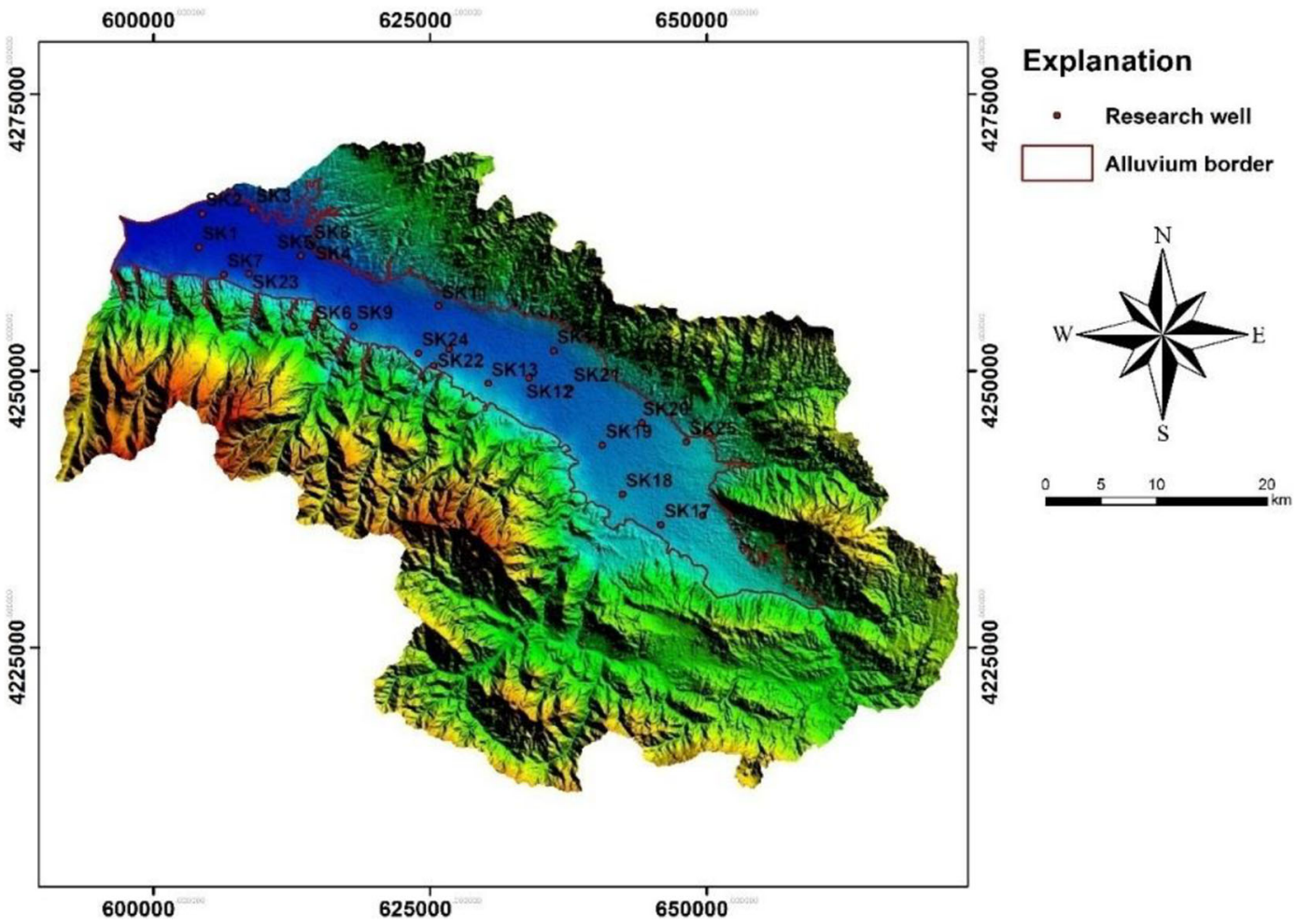

Fig. 9 Research wells in the study area 
where $\theta$ is the water content $[-], \theta_{\mathrm{s}}$ is the saturated water content $[-], \theta_{\mathrm{r}}$ is the residual water content $[-], n, \alpha$ is the parameter and $m=1-\frac{1}{n}$.

$K(h)=K_{S} S_{e}^{l}\left[1-\left(1-S_{e}^{1 / m}\right)^{m}\right]^{2}$

where $K(\mathrm{~h})$ is the hydraulic conductivity in the matric potential $(m)$ (pressure head), $K_{\mathrm{S}}$ is the hydraulic conductivity in saturated conditions, $S_{\mathrm{e}}$ is the effective water content, and $l$ is the parameter describing the pore structure of soil.

There are 6 independent parameters: $\theta_{\mathrm{r}}, \theta_{\mathrm{s}}, \alpha, n, m$, and $l$. The pore connection parameter $l$ in the hydraulic conductivity function is estimated to be about 0.5 on average for most soils (Mualem 1976). The recommended vanGenuchten parameters for 12 different soil types are given in Table 1. vanGenuchten parameters for the research wells are given in Table 2 (Tonkul 2018).

Soil water retention curves, which are called the moisture release curve or drying curve, are often drawn from high water content to low water content. When the soil sample is re-saturated after drying, the matric potential (the pressure head in the unsaturated zone) may not be the same. In the soil water retention curves, the wetting curve is usually drawn below the drying curve. This situation is known as hysteresis. In HYDRUS 1D software program, it is assumed that the value of $\theta_{\mathrm{r}}, \theta_{\mathrm{s}}$, and $n$ remains constant in dry and wet conditions in order to determine the hysteresis (Simunek et al. 2008).

Table 1 vanGenuchten hydraulic parameters for 12 different soil types (Van Genuchten 1980)

\begin{tabular}{lllll}
\hline Soil type & $\begin{array}{l}\theta_{\mathrm{r}} \\
{\left[\mathrm{L}^{3} \mathrm{~L}^{-3}\right]}\end{array}$ & $\begin{array}{l}\theta_{\mathrm{s}} \\
{\left[\mathrm{L}^{3} \mathrm{~L}^{-3}\right]}\end{array}$ & $\begin{array}{l}\alpha \\
{\left[\mathrm{cm}^{-1}\right]}\end{array}$ & $\begin{array}{l}n \\
{[-]}\end{array}$ \\
\hline Sand & 0.053 & 0.375 & 0.035 & 3.18 \\
Loamy sand & 0.049 & 0.0390 & 0.035 & 1.75 \\
Sandy loam & 0.039 & 0.387 & 0.027 & 1.45 \\
Loam & 0.061 & 0.399 & 0.011 & 1.47 \\
Silt & 0.05 & 0.489 & 0.007 & 1.68 \\
Silty loam & 0.065 & 0.439 & 0.005 & 1.66 \\
Sandy clay loam & 0.063 & 0.384 & 0.021 & 1.33 \\
Clay loam & 0.079 & 0.442 & 0.016 & 1.41 \\
Silty clay loam & 0.09 & 0.482 & 0.008 & 1.52 \\
Sandy clay & 0.117 & 0.385 & 0.033 & 1.21 \\
Silty clay & 0.111 & 0.481 & 0.016 & 1.32 \\
Clay & 0.098 & 0.459 & 0.015 & 1.25 \\
\hline
\end{tabular}

Table 2 vanGenuchten parameters of research wells (Tonkul 2018)

\begin{tabular}{|c|c|c|c|c|c|}
\hline $\begin{array}{l}\text { Well ID } \\
\text { (Depth, m) }\end{array}$ & $\begin{array}{l}\theta_{\mathrm{r}} \\
{[-]}\end{array}$ & $\begin{array}{l}\boldsymbol{\theta}_{\mathrm{s}} \\
{[-]}\end{array}$ & $\begin{array}{l}\boldsymbol{\alpha} \\
(1 / m)\end{array}$ & $\begin{array}{l}n \\
{[-]}\end{array}$ & $\begin{array}{l}l \\
{[-]}\end{array}$ \\
\hline $\begin{array}{l}\text { SK-1 } \\
(0-5)\end{array}$ & $\begin{array}{l}0.045 \\
0.034 \\
0.034\end{array}$ & $\begin{array}{l}0.43 \\
0.46 \\
0.46\end{array}$ & $\begin{array}{l}14.5 \\
1.6 \\
1.6\end{array}$ & $\begin{array}{l}2.68 \\
1.37 \\
1.37\end{array}$ & $\begin{array}{l}0.5 \\
0.5 \\
0.5\end{array}$ \\
\hline $\begin{array}{l}\text { SK-2 } \\
(0-2)\end{array}$ & 0.07 & 0.36 & 0.5 & 1.09 & 0.5 \\
\hline $\begin{array}{l}\text { SK-3 } \\
(0-4)\end{array}$ & $\begin{array}{l}0.07 \\
0.068\end{array}$ & $\begin{array}{l}0.36 \\
0.38\end{array}$ & $\begin{array}{l}0.5 \\
0.8\end{array}$ & $\begin{array}{l}1.09 \\
1.09\end{array}$ & $\begin{array}{l}0.5 \\
0.5\end{array}$ \\
\hline $\begin{array}{l}\text { SK-4 } \\
(0-38.5)\end{array}$ & $\begin{array}{l}0.07 \\
0.068 \\
0.07 \\
0.07 \\
0.034\end{array}$ & $\begin{array}{l}0.36 \\
0.38 \\
0.36 \\
0.36 \\
0.46\end{array}$ & $\begin{array}{l}0.5 \\
0.8 \\
0.5 \\
0.5 \\
1.6\end{array}$ & $\begin{array}{l}1.09 \\
1.09 \\
1.09 \\
1.09 \\
1.37\end{array}$ & $\begin{array}{l}0.5 \\
0.5 \\
0.5 \\
0.5 \\
0.5\end{array}$ \\
\hline $\begin{array}{l}\text { SK-5 } \\
(0-3)\end{array}$ & 0.07 & 0.36 & 0.5 & 1.09 & 0.5 \\
\hline $\begin{array}{l}\text { SK-7 } \\
(0-25)\end{array}$ & $\begin{array}{l}0.1 \\
0.045 \\
0.045 \\
0.078\end{array}$ & $\begin{array}{l}0.38 \\
0.43 \\
0.43 \\
0.43\end{array}$ & $\begin{array}{l}2.7 \\
14.5 \\
14.5 \\
3.6\end{array}$ & $\begin{array}{l}1.23 \\
2.68 \\
2.68 \\
1.56\end{array}$ & $\begin{array}{l}0.5 \\
0.5 \\
0.5 \\
0.5\end{array}$ \\
\hline $\begin{array}{l}\text { SK-8 } \\
(0-4)\end{array}$ & 0.1 & 0.38 & 2.7 & 1.23 & 0.5 \\
\hline $\begin{array}{l}\text { SK-10 } \\
(0-21.5)\end{array}$ & $\begin{array}{l}0.1 \\
0.045\end{array}$ & $\begin{array}{l}0.38 \\
0.43\end{array}$ & $\begin{array}{l}2.7 \\
14.5\end{array}$ & $\begin{array}{l}1.23 \\
2.68\end{array}$ & $\begin{array}{l}0.5 \\
0.5\end{array}$ \\
\hline $\begin{array}{l}\text { SK-11 } \\
(0-10)\end{array}$ & 0.1 & 0.38 & 2.7 & 1.23 & 0.5 \\
\hline $\begin{array}{l}\text { SK-12 } \\
(0-9)\end{array}$ & 0.1 & 0.38 & 2.7 & 1.23 & 0.5 \\
\hline $\begin{array}{l}\text { SK-13 } \\
(0-23)\end{array}$ & $\begin{array}{l}0.1 \\
0.034 \\
0.1\end{array}$ & $\begin{array}{l}0.38 \\
0.46 \\
0.38\end{array}$ & $\begin{array}{l}2.7 \\
1.6 \\
2.7\end{array}$ & $\begin{array}{l}1.23 \\
1.37 \\
1.23\end{array}$ & $\begin{array}{l}0.5 \\
0.5 \\
0.5\end{array}$ \\
\hline $\begin{array}{l}\text { SK-14 } \\
(0-25.4)\end{array}$ & $\begin{array}{l}0.1 \\
0.034 \\
0.1\end{array}$ & $\begin{array}{l}0.38 \\
0.46 \\
0.38\end{array}$ & $\begin{array}{l}2.7 \\
1.6 \\
2.7\end{array}$ & $\begin{array}{l}1.23 \\
1.37 \\
1.23\end{array}$ & $\begin{array}{l}0.5 \\
0.5 \\
0.5\end{array}$ \\
\hline $\begin{array}{l}\text { SK-17 } \\
(0-15.8)\end{array}$ & 0.1 & 0.38 & 2.7 & 1.23 & 0.5 \\
\hline $\begin{array}{l}\text { SK-18 } \\
(0-37.8)\end{array}$ & $\begin{array}{l}0.068 \\
0.1 \\
0.1 \\
0.1 \\
0.034 \\
0.1\end{array}$ & $\begin{array}{l}0.38 \\
0.38 \\
0.38 \\
0.38 \\
0.46 \\
0.38\end{array}$ & $\begin{array}{l}0.8 \\
2.7 \\
2.7 \\
2.7 \\
1.6 \\
2.7\end{array}$ & $\begin{array}{l}1.09 \\
1.23 \\
1.23 \\
1.23 \\
1.37 \\
1.23\end{array}$ & $\begin{array}{l}0.5 \\
0.5 \\
0.5 \\
0.5 \\
0.5 \\
0.5\end{array}$ \\
\hline $\begin{array}{l}\text { SK-19 } \\
(0-17.1)\end{array}$ & 0.068 & 0.38 & 0.8 & 1.09 & 0.5 \\
\hline $\begin{array}{l}\text { SK-20 } \\
(0-19.9)\end{array}$ & $\begin{array}{l}0.034 \\
0.068 \\
0.045\end{array}$ & $\begin{array}{l}0.46 \\
0.38 \\
0.43\end{array}$ & $\begin{array}{l}1.6 \\
0.8 \\
14.5\end{array}$ & $\begin{array}{l}1.37 \\
1.09 \\
2.68\end{array}$ & $\begin{array}{l}0.5 \\
0.5 \\
0.5\end{array}$ \\
\hline $\begin{array}{l}\text { SK-21 } \\
(0-37)\end{array}$ & $\begin{array}{l}0.034 \\
0.1 \\
0.045 \\
0.068\end{array}$ & $\begin{array}{l}0.46 \\
0.38 \\
0.43 \\
0.38\end{array}$ & $\begin{array}{l}1.6 \\
2.7 \\
14.5 \\
0.8\end{array}$ & $\begin{array}{l}1.37 \\
1.23 \\
2.68 \\
1.09\end{array}$ & $\begin{array}{l}0.5 \\
0.5 \\
0.5 \\
0.5\end{array}$ \\
\hline $\begin{array}{l}\text { SK-22 } \\
(0-25.74)\end{array}$ & $\begin{array}{l}0.1 \\
0.045 \\
0.078\end{array}$ & $\begin{array}{l}0.38 \\
0.43 \\
0.43\end{array}$ & $\begin{array}{l}2.7 \\
14.5 \\
3.6\end{array}$ & $\begin{array}{l}1.23 \\
2.68 \\
1.56\end{array}$ & $\begin{array}{l}0.5 \\
0.5 \\
0.5\end{array}$ \\
\hline $\begin{array}{l}\text { SK-23 } \\
(0-10.53)\end{array}$ & $\begin{array}{l}0.078 \\
0.045\end{array}$ & $\begin{array}{l}0.43 \\
0.43\end{array}$ & $\begin{array}{l}3.6 \\
14.5\end{array}$ & $\begin{array}{l}1.56 \\
2.68\end{array}$ & $\begin{array}{l}0.5 \\
0.5\end{array}$ \\
\hline
\end{tabular}


Only the $\alpha$ parameter changes (Anlauf et al. 2012). For this reason, no hysteresis option was selected in HYDRUS 1D.

\section{Result and discussion}

\section{Meteorological characteristics}

Three weather stations were installed Yeşilova (MT-1), Alhan (MT-2), and Çavuşlar (MT-3) regions (Fig. 10). The meteorological data such as the amount of precipitation, wind direction and speed, humidity, and air temperature were measured from these stations. All three stations have a data bank that records data every 1 hour and was set to measure the same parameters at the same time intervals. Stations belonging to the General Directorate of State Hydraulic Works (DSI) and the General Directorate of Meteorology, which are located in the basin, were taken into consideration in the location selection of the stations.

From July 16, 2016, to July 31, 2017, meteorological data were collected from these weather stations on a regular basis for 1 year. At the same time, using Thornthwaite method, potential evapotranspiration (PET), actual evapotranspiration, and runoff values of Alaşehir sub-basin were determined by using monthly average temperature values obtained from weather stations.

One-year long-term meteorological monitoring studies were carried out at the weather stations located at three different locations in the study area. Accordingly, daily temperature and rainfall change graphs for meteorological stations were presented in Figs. 11, 12, and 13.

The highest temperature recorded by the Yeșilova (MT-1) weather station was $41.6{ }^{\circ} \mathrm{C}$ in July 2017 , while the lowest temperature was measured as $-5.9{ }^{\circ} \mathrm{C}$ in December 2016 (Fig. 11a).

Accordingly, there is a similarity between daily temperature change and rainfall graphs recorded at all three weather stations. When the daily temperature change graphs recorded by the weather stations of Yeşilova (MT-1), Alhan (MT-2), and Çavuşlar (MT-3) are dealt, the lowest temperatures measured for the Alaşehir subbasin are between November 2016 and March 2017 (Figs. 11a, 12, 13a).

The mean minimum and maximum temperatures measured for the study area from the three weather stations were obtained as $5.8^{\circ} \mathrm{C}$ and $30.05^{\circ} \mathrm{C}$, respectively.

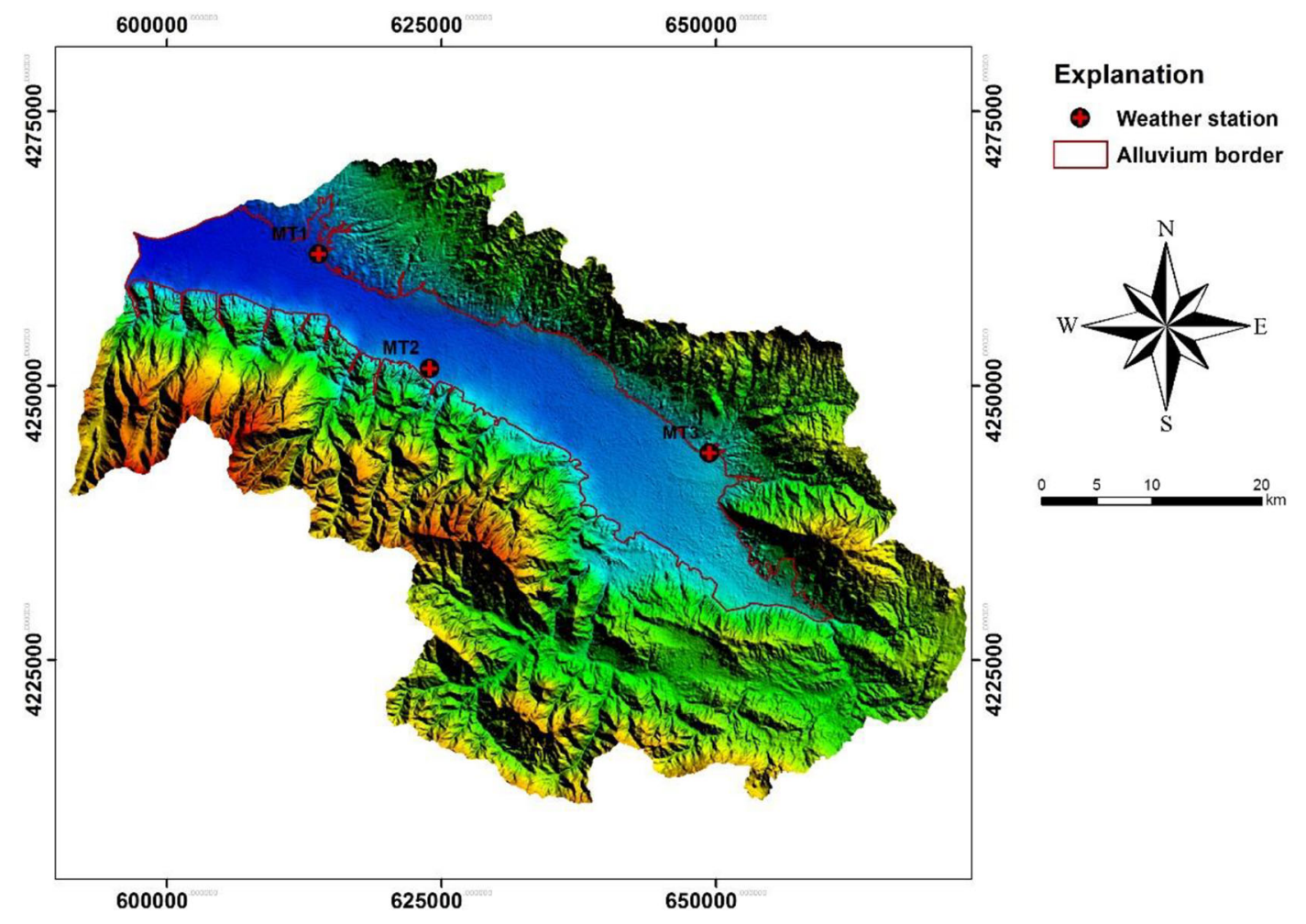

Fig. 10 Location of weather stations 
Fig. 11 Daily temperature (a) and rainfall change (b) graphs of the Yeșilova (MT-1) weather station
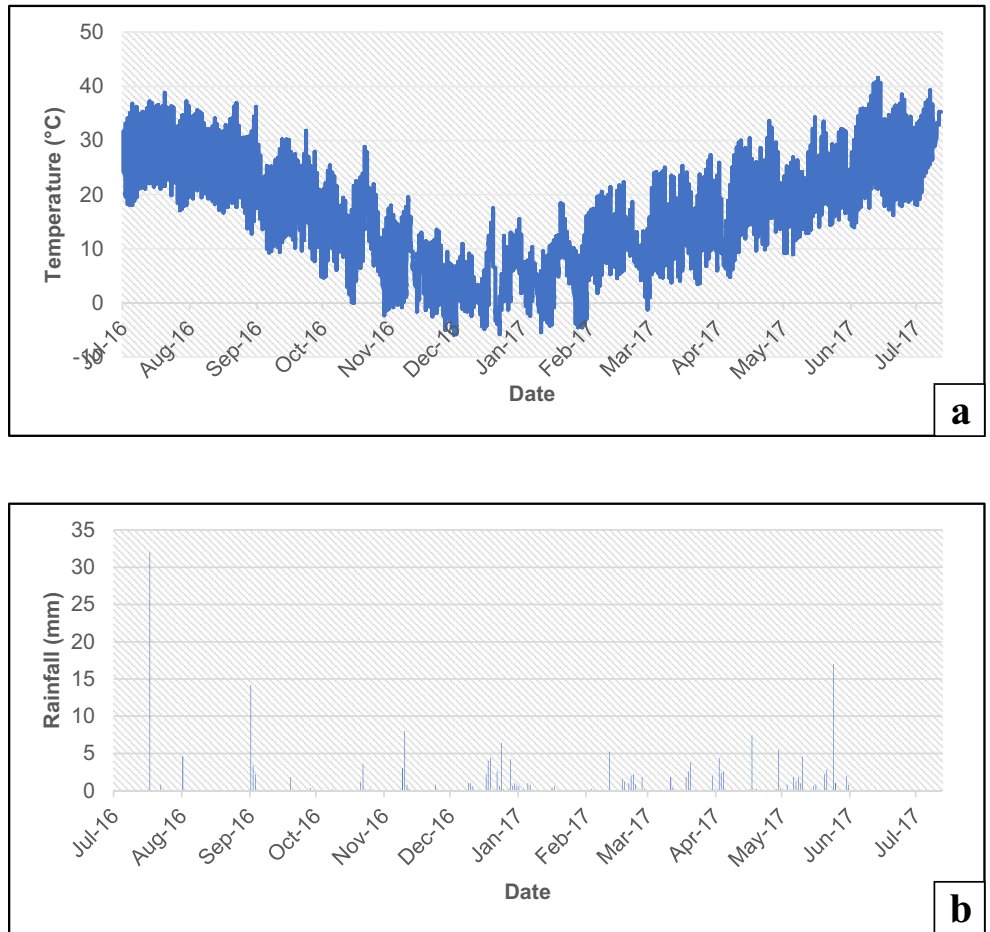

Using the daily temperature from the weather stations, the potential evapotranspiration values for the basin were first determined by the Thornthwaite method and then the actual evapotranspiration and runoff values were obtained.
Fig. 12 Daily temperature (a) and rainfall change (b) graphs of the Alhan (MT-2) weather station
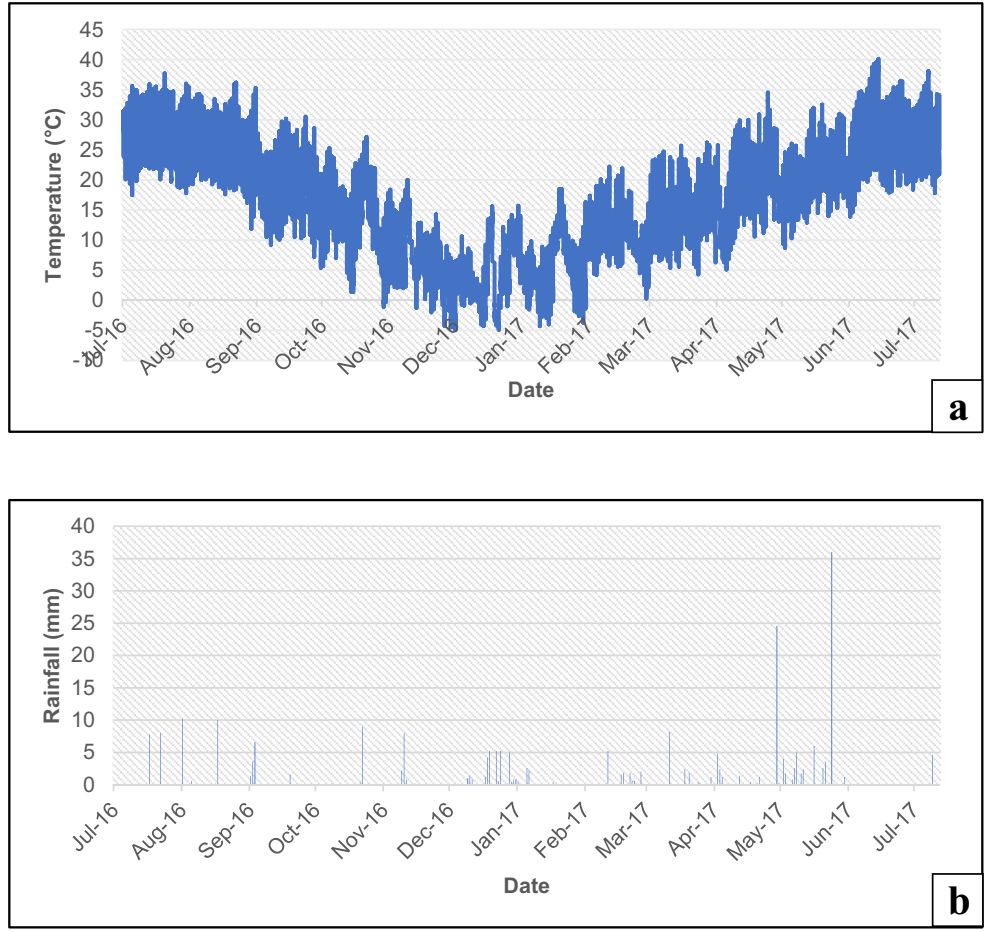
Fig. 13 Daily temperature (a) and rainfall change (b) graphs of the Çavușlar (MT-3) weather station
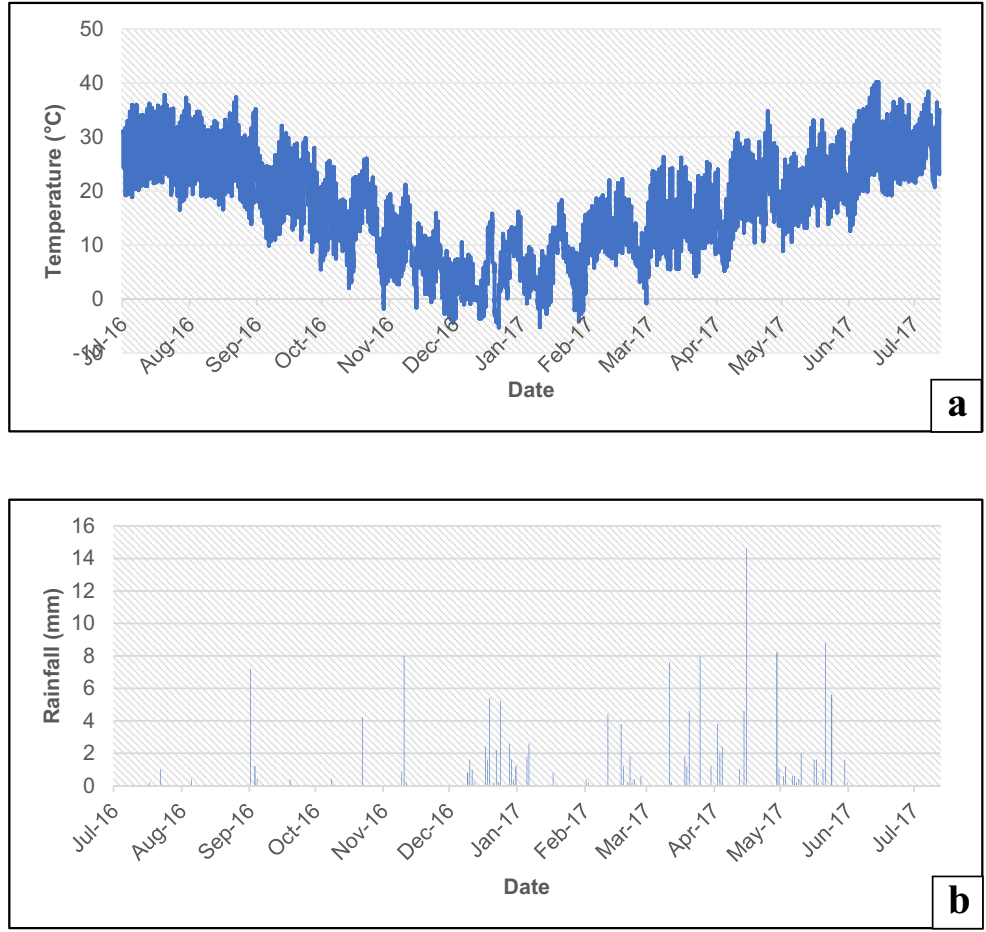

Thornthwaite method

The Thornthwaite method is one of the methods developed to determine the amount of evaporation in drainage basins. This method is based on empirical methods derived from precipitation for many drainage basins and potential evaporation values can be found with Eq. (5) (Thornthwaite 1948).

$$
P E T=1.6 \times(10 T / I)^{a}
$$

$$
\begin{aligned}
a= & 6.7 \times 10^{-7} \times I^{3}-7.7 \times 10^{-5} \times I^{2}+1.8 \\
& \times 10^{-2} \times I+0.49
\end{aligned}
$$

where $T$ is the monthly mean temperature $\left({ }^{\circ} \mathrm{C}\right), I$ is the heat index value at the given average temperature, and $a$ is the exponent defined as the function of the heat index. Thornthwaite (1948) noted that a long-term meteorological data is needed in this method, which is widely used in climate classification of any region. Monthly mean temperature values for the Alașehir sub-basin were monitored from data obtained from meteorological stations for 1 year (Figs. 14, 15, and 16). The heat index values corresponding to the obtained average monthly temperature values were obtained from the Thornthwaite heat index table (Table 3).

The heat index values corresponding to the average monthly temperature values are presented in Table 4 . Sunshine periods for the Alaşehir sub-basin were obtained from the Ministry of Energy and Natural Resources website (E.İ.E 2017). The monthly average temperature values in Table 4 are average values obtained from all three meteorological stations.

These values were then multiplied by the latitude correction coefficient according to the sunshine hours and the geographical latitude of the study area, and the potential evapotranspiration values for the Alaşehir subbasin were calculated. From this, actual evapotranspiration and runoff values were obtained for the study area (Table 5).

Potential evapotranspiration (PET) refers to the evaporation that occurs when there is maximum humidity in the environment. The potential evapotranspiration values with the increasing humidity in Alasehir subbasin have the highest levels in summer. Actual evapotranspiration is computed to be less than the potential evapotranspiration values because it is limited only to soil moisture. The actual evapotranspiration value computed for the study area for a total of 1 year is 408.91 $\mathrm{mm} /$ year. 
Fig. 14 Monthly mean temperature change graph of Yeșilova (MT-1) weather station for 1 year

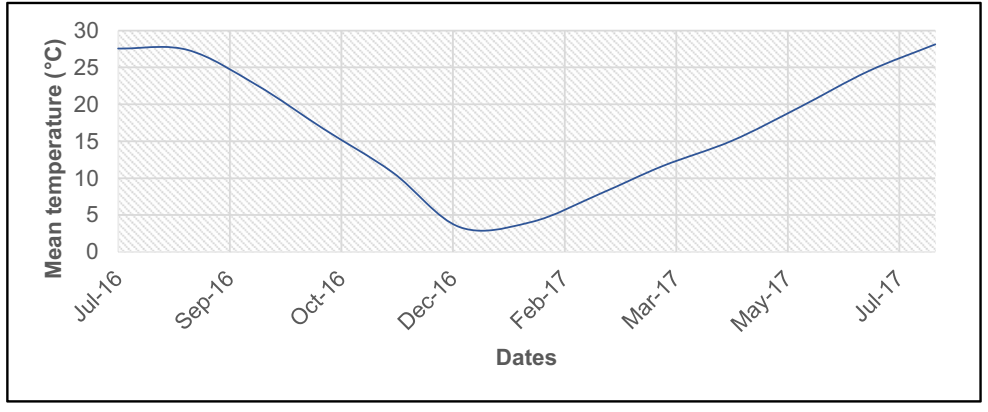

The potential evapotranspiration values in the Alaşehir sub-basin are well above the rainfall for a 1year period. Thus, the total annual potential evapotranspiration is computed as $902.92 \mathrm{~mm} /$ year, while the total annual rainfall is measured as $457 \mathrm{~mm} /$ year. Accordingly, in the months when the potential evapotranspiration was above the rainfall, runoff was computed as $0 \mathrm{~mm}$. For Alașehir sub-basin, runoff is $0.66 \mathrm{~mm}$ in November 2016, $93 \mathrm{~mm}$ in January 2017, and $3.88 \mathrm{~mm}$ in March 2017 and total runoff was obtained as 97.54 $\mathrm{mm} /$ year. Note that rainfall is much more than the potential evapotranspiration in these months (Table 5).

According to the data obtained from weather stations, it was concluded that the study area is the continental transition characteristic from the inner Aegean and Mediterranean climate. The annual mean temperature value in the Alaşehir sub-basin was measured as $16.25^{\circ} \mathrm{C}$. When the temperature change graphs of the Alaşehir sub-basin are examined, it is seen that the mean temperature value is much higher than the annual mean temperature value. The fact that the long-term mean temperature is higher than the annual mean temperature indicates that the basin has an arid period. In addition, the fact that the high evaporation values in the study area are higher than the rainfall is evidence that the Alaşehir sub-basin is located in an arid climate region (Tonkul 2018).
Alluvium aquifer recharge computation

\section{HYDRUS 1D model simulation}

In HYDRUS 1D modeling, first, depth of the soil layer in vadose zone, axis of water movement, and number of materials were entered as input; the length unit was determined in meters and time period was selected as year. Profile discretization was made by dividing it into 101 nodes for one research well.

In HYDRUS 1D program, the number of time variable boundary records was selected as 12 for 1 year period. The wide array of time scales required to efficiently simulate the flow pathways is the most important problem of the modeling. Therefore, unsaturated flow numerically requires small time steps in the order of seconds to describe the vertical movement of moisture in the unsaturated domain, whereas the groundwater flow can be run with time steps in the order of days.

Finally, weather data obtained from weather stations were assigned to the program and the model was created separately for each research well, selecting appropriate initial and boundary conditions. Weather station data is given in Table 5.
Fig. 15 Monthly mean temperature change graph of Alhan (MT-2) weather station for 1 year

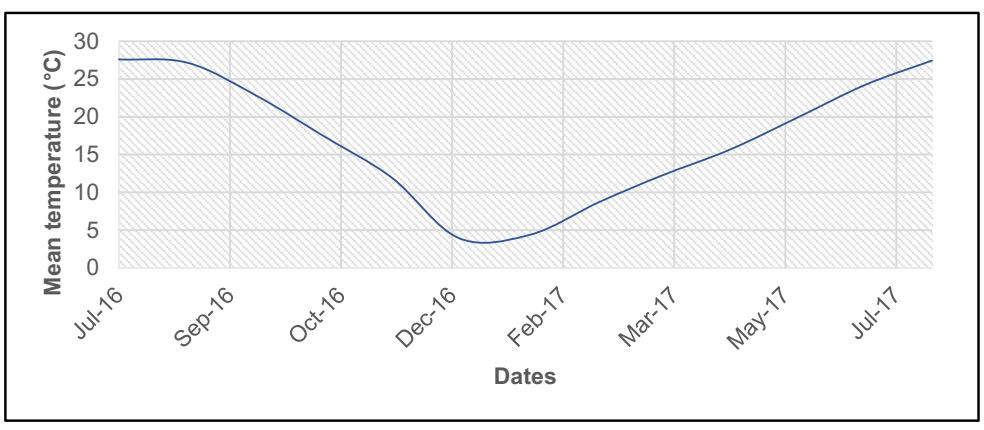


Fig. 16 Monthly mean temperature change graph of Çavuşlar (MT-3) weather station for 1 year

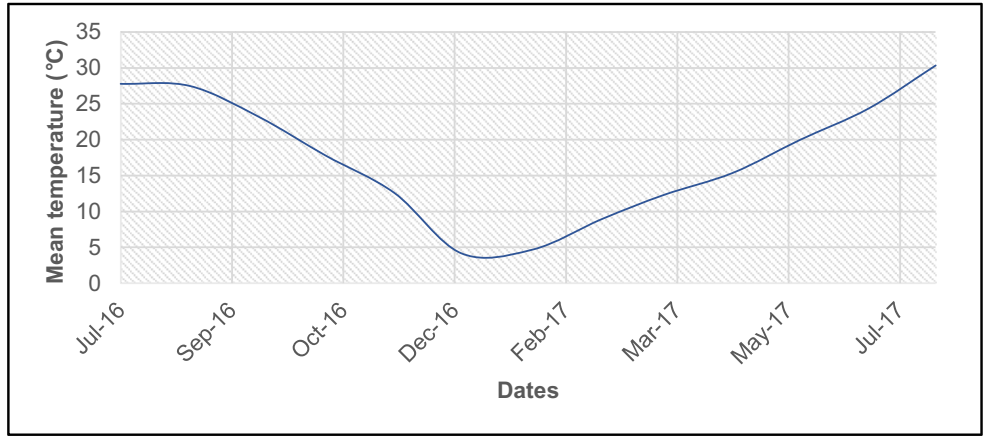

\section{Initial and boundary condition}

Initial condition The solution of groundwater flow equations requires the specifications of appropriate initial and boundary conditions. HYDRUS 1D allows the use of the following initial conditions for water content and pressure head;

$\theta(z, t)=\theta_{i}(z, 0)$,

$h(z, t)=h_{i}(z, 0)$,

where $\theta_{\mathrm{i}}[-]$ and $h_{\mathrm{i}}[\mathrm{L}]$ represent water content and pressure head, respectively. Accordingly, water content values of the vadose zone determined in the laboratory were used in the study as initial condition (Eq. (7)).

Boundary conditions The atmospheric boundary condition with surface runoff is one of the system-dependent boundary conditions of HYDRUS-1D program, which represents the soil-air interface exposed to atmospheric conditions. In atmospheric boundary condition with surface runoff, the potential flow is completely controlled by meteorological conditions such as precipitation and evaporation along this interface. The soil surface boundary conditions may vary from the predicted flow to the predicted head conditions. This occurs when the precipitation exceeds the infiltration capacity of the soil. On the other hand, it causes the rainwater to accumulate on the soil layer depending on soil conditions.

Free drainage boundary condition can be applied if there is groundwater below the flow domain. Free drainage boundary condition cannot be used for edges of flow domain. For this purpose, the bottom of the flow domain was selected as free drainage boundary condition. While determining the upper and lower boundaries, it is assumed that infiltration takes place only in the vertical direction for vadose zone and no flux occurs from lateral boundary.

\section{Model calibration and validation}

Model calibration is generally defined as the process of tuning a model for a particular problem by manipulating the input parameters (e.g., soil hydraulic parameters)

Table 3 Heat index values calculated by Thornthwaite (1948)

\begin{tabular}{lllllllllll}
\hline Temperature $\left({ }^{\circ} \mathrm{C}\right)$ & 0 & 0.1 & 0.2 & 0.3 & 0.4 & 0.5 & 0.6 & 0.7 & 0.8 & 0.9 \\
\hline 0 & 0 & 0 & 0.01 & 0.01 & 0.02 & 0.03 & 0.04 & 0.05 & 0.06 & 0.07 \\
5 & 1.00 & 1.03 & 1.06 & 1.09 & 1.12 & 1.16 & 1.19 & 1.22 & 1.25 & 1.28 \\
10 & 2.86 & 2.90 & 2.94 & 2.99 & 3.03 & 3.07 & 3.12 & 3.16 & 3.21 & 3.25 \\
15 & 5.28 & 5.33 & 5.38 & 5.44 & 5.49 & 5.55 & 5.60 & 5.65 & 5.71 & 5.76 \\
20 & 8.16 & 8.22 & 8.28 & 8.34 & 8.41 & 8.47 & 8.53 & 8.59 & 8.66 & 8.72 \\
25 & 11.44 & 11.50 & 11.57 & 11.64 & 11.71 & 11.78 & 11.85 & 11.92 & 11.99 & 12.06 \\
30 & 15.07 & 15.15 & 15.22 & 15.3 & 15.38 & 15.45 & 15.53 & 15.61 & 15.68 & 15.76 \\
35 & 19.03 & 19.11 & 19.20 & 19.28 & 19.36 & 19.44 & 19.53 & 19.61 & 19.69 & 19.78 \\
40 & 23.30 & 23.38 & 23.47 & 23.56 & 23.65 & 23.74 & 23.83 & 23.92 & 24.00 & 24.09 \\
\hline
\end{tabular}


Table 4 Monthly mean temperature and heat index values of the Alaşehir sub-basin (Tonkul 2018)

\begin{tabular}{lllll}
\hline Months & Mean temperature $\left({ }^{\circ} \mathrm{C}\right)$ & Heat index $(I)$ & Sunshine hours $(\mathrm{h})$ & $\begin{array}{l}\text { Latitude } \\
\text { correction }\end{array}$ \\
\hline January & 4.4 & 0.82 & 4.6 & 0.85 \\
February & 8.5 & 2.23 & 5.45 & 0.84 \\
March & 12 & 3.76 & 6.57 & 1.03 \\
April & 15.4 & 5.49 & 7.62 & 1.10 \\
May & 19.8 & 8.03 & 9.49 & 1.23 \\
June & 24.4 & 11.02 & 11.32 & 1.24 \\
July & 27.6 & 13.28 & 11.77 & 1.25 \\
August & 27.3 & 13.07 & 11.06 & 1.17 \\
September & 22.9 & 10.01 & 9.26 & 1.04 \\
October & 17.3 & 6.55 & 7.11 & 0.96 \\
November & 11.7 & 3.62 & 5.22 & 0.84 \\
December & 3.8 & 0.66 & 3.94 & 0.83 \\
\hline
\end{tabular}

and initial or boundary conditions within reasonable ranges until the simulated model results closely match the observed variables. In the HYDRUS 1D, inverse modeling is a form of model calibration. Inverse modeling requires a set of observed data, such as measured water contents or pressure heads. In model calibration, the objective is usually to obtain better model predictions. The HYDRUS models have an inverse modeling capability.

In this study, monthly mean observed water contents from soil moisture sensor located in Hacilı region and SK-2 well were used to calibrate HYDRUS 1D model. For the calibration stage, the observed and simulated water contents are shown in
Fig. 17 where the observed water content is simulated well, with $R^{2}=0.75$.

Figure 17 illustrated a good agreement between modeled and observed soil moisture content as indicated by high $R^{2}$ which was found to be 0.75 . Again, it concluded a good agreement between modeled and observed pressure head (Fig. 18).

Based on these results, the limitations of the HYDRUS 1D model are given as follows:

- Core drilling and laboratory tests are needed for the HYDRUS 1D model.

- HYDRUS 1D model can only be modeled using research drilling data.

Table 5 Weather data for the Alaşehir sub-basin (Tonkul 2018)

\begin{tabular}{lllll}
\hline Months & Rainfall $(\mathrm{mm})$ & Actual evapotranspiration $(\mathrm{mm})$ & Potential evapotranspiration (mm) & Runoff (mm) \\
\hline July-16 & 0.00 & 8.29 & 180.68 & 0.00 \\
August-16 & 27.87 & 27.87 & 165.91 & 0.00 \\
September-16 & 28.67 & 28.67 & 108.40 & 0.00 \\
October-16 & 2.13 & 2.13 & 61.22 & 0.00 \\
November-16 & 77.33 & 27.00 & 27.00 & 0.66 \\
December-16 & 15.67 & 3.72 & 3.72 & 0.00 \\
January-17 & 97.93 & 4.93 & 4.93 & 93.00 \\
February-17 & 1.87 & 15.43 & 15.43 & 0.00 \\
March-17 & 43.33 & 34.61 & 34.61 & 3.88 \\
April-17 & 55.80 & 57.22 & 57.22 & 0.00 \\
May-17 & 61.60 & 99.37 & 99.37 & 0.00 \\
June-17 & 43.70 & 99.67 & 144.43 & 0.00 \\
\hline
\end{tabular}




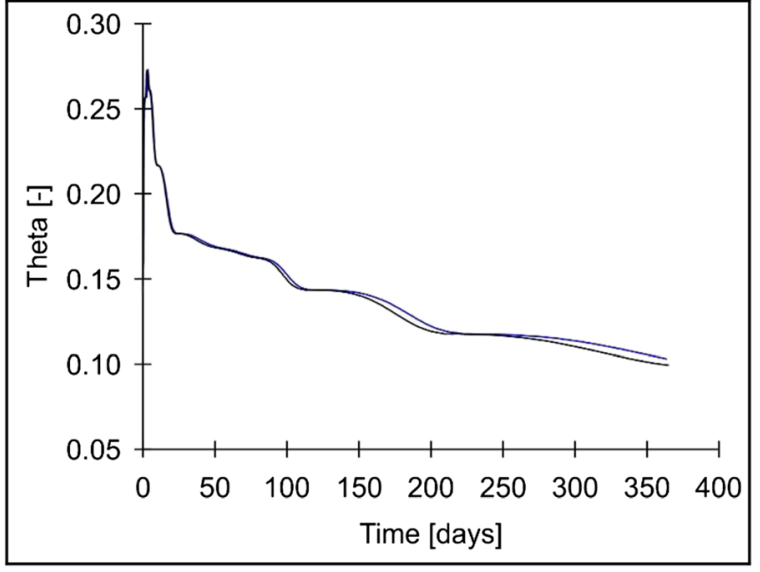

Fig. 17 Observed (black curve) and simulated (blue curve) water content in the parameter optimization

- HYDRUS 1D models only the vertical flow as a point.

- For point-based uses, the model only gives surface infiltration and does not take into account the lateral recharge of the aquifer.

- HYDRUS 1D can be used in regional or natural groundwater recharge studies rather than aquiferbased studies.

\section{Alluvium aquifer recharge}

HYDRUS 1D model was then applied to predict the natural recharge values for the research wells. The obtained values are presented in Table 6 .

The recharge values range from 21.78 to $68.52 \mathrm{~mm} /$ year, and the mean value of the recharge was obtained

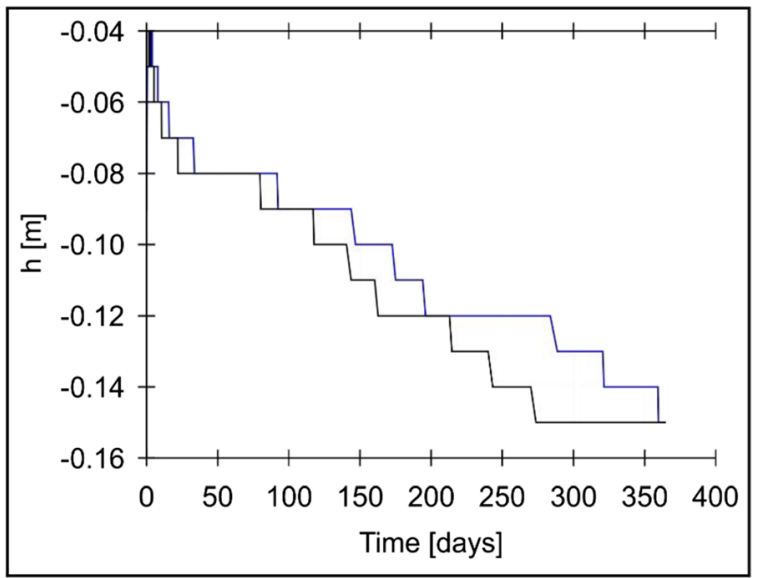

Fig. 18 Observed (black curve) and simulated (blue curve) pressure head in the parameter optimization
$43.09 \mathrm{~mm} /$ year (Table 6). This value accounts for $10 \%$ of the precipitation rate employed in HYDRUS-1D program. About $10 \%$ recharge value represents the recharge coefficient for the study area. In order to be able to interpret how recharge values are distributed within the basin in the modeling study, a spatial distribution map of point recharge values was prepared (Fig. 19). Alaşehir sub-basin recharge values distribution map was created in the GIS by using interpolation method.

The obtained HYDRUS 1D point recharge values do not reflect recharge in permeable stream beds and coastal alluvial fans. As shown in Fig. 19, higher recharge values were obtained in the west part of the basin, while lower recharge values were obtained in the east of the basin. The highest recharge values were obtained in SK3, SK-4, SK-7, SK-18, and SK-22 wells. It is thought that the most important factor here is the soil class in the unsaturated zone. When SK-18 and SK-17 wells were compared, the presence of some gravel units in well of SK-18 directly increased the recharge value (Fig. 19).

The west part of the basin contains some gravel units compared with east parts. Therefore, higher recharge values were obtained in the west part of the study area (Fig. 19). Recharge values obtained from the HYDRUS model yielded results consistent with alluvium aquifer hydraulic conductivity distribution map. It has been concluded that in the basin where the hydraulic conductivity increases, the recharge values increase. Therefore, the recharge mechanism of the alluvium aquifer is controlled by soil class and hydraulic conductivity values.

In HYDRUS model, the value of water mass on the surface to vertical infiltration is considered. Rainwater is retained as water content when passing through unsaturated zone.

Within the scope of the study, aquifer-based groundwater recharge method was applied and a comprehensive database on aquifer was presented. In line with the targeted aim, an accumulation of knowledge has been revealed to lead the studies to be carried out in the alluvial aquifer such as Alașehir region.

The results mentioned above have been compared with the results of some researchers and similar relationships have been obtained (Batalha et al. 2018; Caiqiong and Jun 2016; Dandekar et al. 2018; Hou et al. 2017; Kambale et al. 2017; Melki et al. 2017; Nasta et al. 2018; Szymkiewicz et al. 2018; Vogel 2019; Yang et al. 2019). The most important difference of this study from other groundwater recharge studies or hydrogeological studies carried out in Turkey was to 
Table 6 Groundwater recharge values of research wells (Tonkul 2018)

\begin{tabular}{|c|c|c|c|}
\hline Well ID & Location & Recharge (m/year) & Recharge (mm/year) \\
\hline SK-1 & Karaoğlanlı & 0.034832 & 34.83 \\
\hline SK-2 & Taytan & 0.021783 & 21.78 \\
\hline SK-3 & Durasallı & 0.060552 & 60.55 \\
\hline SK-4 & YeșilovaTepe & 0.060045 & 60.04 \\
\hline SK-5 & YeșilovaMera & 0.022264 & 22.26 \\
\hline SK-7 & Kabazlı & 0.062007 & 62.00 \\
\hline SK-8 & Hacilı & 0.052719 & 52.71 \\
\hline SK-10 & Piyadeler & 0.036315 & 36.31 \\
\hline SK-11 & Toygarlı & 0.036284 & 36.28 \\
\hline SK-12 & Baklacı & 0.034362 & 34.36 \\
\hline SK-13 & Akkeçili & 0.037306 & 37.30 \\
\hline SK-14 & Tepeköy & 0.036329 & 36.32 \\
\hline SK-17 & Ahmetağa & 0.036662 & 36.66 \\
\hline SK-18 & Haceli & 0.068521 & 68.52 \\
\hline SK-19 & Sobran & 0.034228 & 34.22 \\
\hline SK-20 & Yeșilyurt & 0.036294 & 36.29 \\
\hline SK-21 & Ilgin & 0.038805 & 38.80 \\
\hline SK-22 & Piyadeler & 0.062595 & 62.59 \\
\hline \multirow[t]{2}{*}{ SK-23 } & Yeşilkavak & 0.046808 & 46.80 \\
\hline & Mean & & 43.09 \\
\hline
\end{tabular}

be made aquifer-based characterization and to be opened observation wells for recharge. In this context, it is proposed to create a groundwater flow model for each aquifer at the next stage of this study.

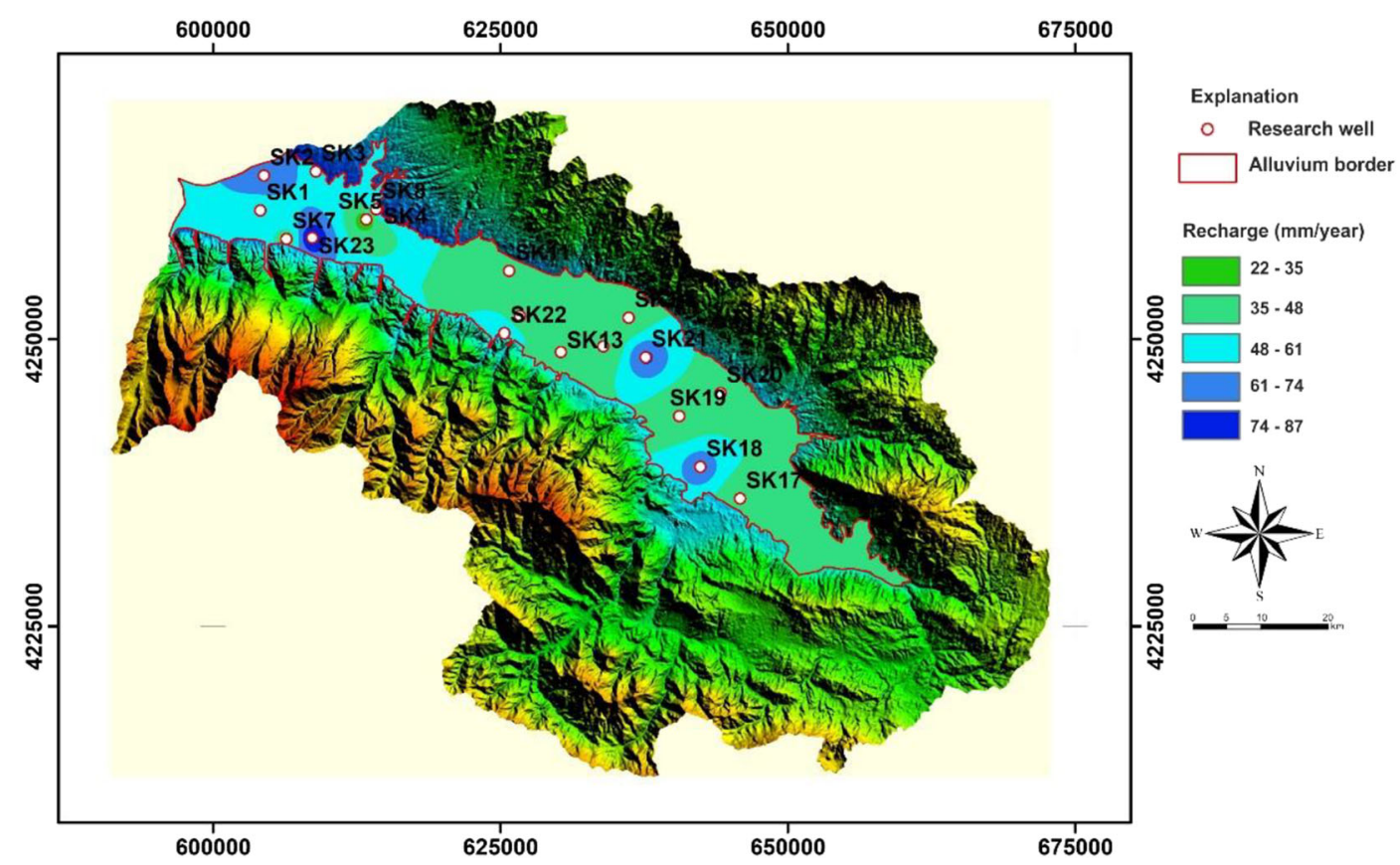

Fig. 19 Alaşehir sub-basin recharge values distribution map created according to HYDRUS 1D model 


\section{Conclusions}

In the study area, in recent years, groundwater usage has increased due to the decrease in surface water resources and precipitation. Alașehir sub-basin is one of the most important agricultural basins where the grape cultivation takes place. In the Alassehir basin, which is under the influence of excessive groundwater withdrawal due to being an agricultural basin, there has been a rapid decrease in groundwater levels. Another factor which causes the decrease in groundwater level is the uncontrolled drilling wells. In the basin, where the climate is generally temperate, summer is quite hot and arid. The rainfall is particularly prevalent in spring and summer. Especially in the Aegean region including the study area, meteorological data reveal that the decrease of precipitation and the increase of evaporation amounts are influenced by the climate change of the region. In order to determine the impact of climate change and excessive groundwater withdrawal in the study area, groundwater recharge study was conducted. In this context, HYDRUS 1D numerical model was used to determine the annual recharge value of the research wells for 1 year in the Alaşehir sub-basin.

According to HYDRUS 1D numerical model results, the recharge value of annual rainfall is between 21.78 and $68.52 \mathrm{~mm}$ and the recharge value from the average rainfall is $43.09 \mathrm{~mm}$. The amount of recharge obtained from direct rainfall corresponds to $10 \%$ of the amount of rainfall. This value also represents the recharge coefficient for the study area. HYDRUS 1D model can be employed for simulating vertical movement of flow, to estimate spatial and temporal change in soil moisture content and to predict recharge rates.

According to the recharge values, it concluded that high evaporation values and excessive water withdrawal in the Alaşehir sub-basin will continue to threaten groundwater resources today and in the future. In addition, the decline in rainfall will continue to threaten groundwater levels, as well. If there is no solution to the problems addressed in the Alaşehir basin, there will be much more important problems related to the decline of groundwater levels in the coming period.

Funding information This work was financially supported by Scientific and Technological Research Council of Turkey (TÜBİTAK) with the project number of $115 \mathrm{Y} 065$.

\section{References}

Anlauf, R., Rehrmann, P., \& Schacht, H. (2012). Simulation of water uptake and redistribution in growing media during ebband-flow irrigation. Journal of Horticulture and Forestry, $4(1), 8-21$.

Batalha, M. S., Barbosa, M. C., Faybishenko, B., \& Van Genuchten, M. T. (2018). Effect of temporal averaging of meteorological data on predictions of groundwater recharge. Journal of Hydrology and Hydromechanics, 66(2), 143-152.

Blonquist, J., Jr., Jones, S. B., \& Robinson, D. (2006). Precise irrigation scheduling for turfgrass using a subsurface electromagnetic soil moisture sensor. Agricultural Water Management, 84(1-2), 153-165.

Brooks, R. H., \& Corey, A.T. (1964). Hydraulic properties of porous media, Hydrol. Paper No. 3, Colorado State Univ., Fort Collins, CO.

Caiqiong, Y., \& Jun, F. (2016). Application of HYDRUS-1D model to provide antecedent soil water contents for analysis of runoff and soil erosion from a slope on the Loess Plateau. Catena, 139(1-8), 1-8.

Çiftçi, N. B., \& Bozkurt, E. (2009). Evolution of the Miocene sedimentary fill of the Gediz Graben, SW Turkey. Sedimentary Geology, 216, 49-79.

Dandekar, A., Singh, D., Sarangi, A., \& Singh, A. (2018). Modelling vadose zone processes for assessing groundwater recharge in semi-arid region. Current Science, 114(3), 608618.

De Silva, C. (2015). Simulation of potential groundwater recharge from the Jaffna Peninsula of Sri Lanka using HYDRUS-1D Model. OUSL Journal, 7, 43.

Devine, R. S. (1995). The trouble with dams. Atlantic Monthly, 276(2), 64-74.

Durner, W. (1994). Hydraulic conductivity estimation for soils with heterogeneous pore structure. Water Resources Research, 32(9), 211-223.

E.İ.E. (2017). Güneș Enerjisi Potansiyel Atlası (GEPA). Retrieved from Türkiye Cumhuriyeti Enerji ve Tabi Kaynaklar Bakanlığı: http://www.eie.gov.tr/MyCalculator/pages/45. aspx.

Hou, L., Zhou, Y., Bao, H., \& Wenninger, J. (2017). Simulation of maize (Zea mays L.) water use with the HYDRUS-1D model in the semi-arid Hailiutu River catchment, Northwest China. Hydrological Sciences Journal, 62(1), 93-103.

Kambale, J., Singh, D., \& Sarangi, A. (2017). Impact of climate change on groundwater recharge in a semi-arid region of northern India. Applied Ecology and Environmental Research, 15(1), 335-362.

Knoppers, R., \& van Hulst, W. (1995). De keerzijde van de dam: Novib.

Kosugi, K. (1996). Lognormal distribution model for unsaturated soil hydraulic properties. Water Resources Research, 32(9), 2697-2703

Melki, A., Abdollahi, K., Fatahi, R., \& Abida, H. (2017). Groundwater recharge estimation under semi arid climate: case of Northern Gafsa watershed, Tunisia. Journal of African Earth Sciences, 132, 37-46.

Mualem, Y. (1976). A new model for predicting the hydraulic conductivity of unsaturated porous media. Water Resources Research, 12(3), 513-522. 
Nasta, P., Adane, Z., Lock, N., Houston, A., \& Gates, J. B. (2018). Links between episodic groundwater recharge rates and rainfall events classified according to stratiform-convective storm scoring: a plot-scale study in eastern Nebraska. Agricultural and Forest Meteorology, 259, 154-161.

Pearce, F. (1992). The dammed: rivers, dams, and the coming world water crisis.

Richards, L. A. (1931). Capillary conduction of liquids through porous mediums. Physics, 1(5), 318-333.

Rushton, K., \& Ward, C. (1979). The estimation of groundwater recharge. Journal of Hydrology, 41(3), 345-361.

Simunek, J., Köhne, J. M., Kodešová, R., \& Šejna, M. (2008). Simulating non equilibrium movement of water, solutes, and particles using HYDRUS: a review of recent applications. Soil and Water Research, 3(Special Issue 1), S42-S51.

Szymkiewicz, A., Gumuła-Kawęcka, A., Šimůnek, J., Leterme, B., Beegum, S., Jaworska-Szulc, B., \& Jacques, D. (2018). Simulations of freshwater lens recharge and salt/freshwater interfaces using the HYDRUS and SWI2 packages for MODFLOW. Journal of Hydrology and Hydromechanics, 66(2), 246-256.

Thornthwaite, C. W. (1948). An approach toward a rational classification of climate. Geographical Review, 38(1), 55-94.
Tonkul, S. (2018). Natural groundwater recharge in the Alaşehir Sub-basin (Gediz Basin, Turkey), İzmir Institute of Technology, The Graduate School of Engineering \& Science, Master Thesis

Van Genuchten, M. T. (1980). A closed-form equation for predicting the hydraulic conductivity of unsaturated soils 1 . Soil Science Society of America Journal, 44(5), 892-898.

Vogel, M. (2019). Effects of model spin-up on simulated recharge using the Hydrus-1D vadose zone model.

Vogel, T., \& Cislerova, M. (1988). On the reliability of unsaturated hydraulic conductivity calculated from the moisture retention curve. Transport in Porous Media, 3, 1-15.

Yang, Z.-Y., Wang, K., Yuan, Y., Huang, J., Chen, Z.-J., \& Li, C. (2019). Non-negligible lag of groundwater infiltration recharge: a case in Mu Us Sandy Land, China. Water, 11(3), 561.

Publisher's note Springer Nature remains neutral with regard to jurisdictional claims in published maps and institutional affiliations. 